\title{
DETERMINANTS OF SECONDARY SCHOOL CHOICE IN THE CZECH REPUBLIC
}

\section{Lenka Drnáková}
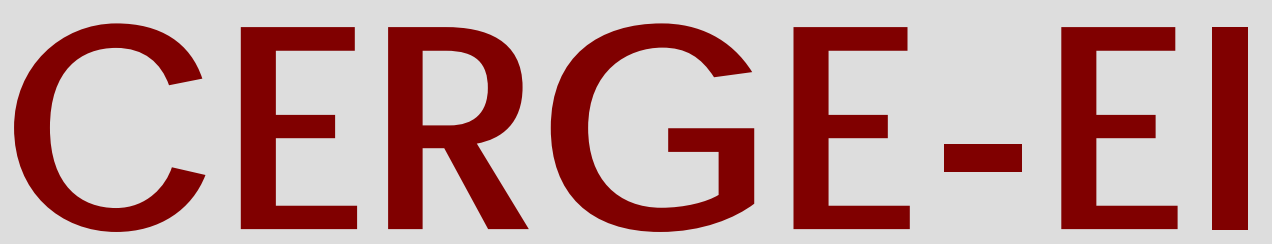

Charles University Centerfor Ec onomic Research and Graduate Education Academy of Sciences of the Czech Republic Ec onomic Institute 


\title{
Working Paper Series 341 (ISSN 1211-3298)
}

\section{Determinants of Secondary School Choice in the Czech Republic}

\author{
Lenka Drnáková
}

CERGE-EI

Prague, September 2007 
ISBN 978-80-7343-140-2 (Univerzita Karlova. Centrum pro ekonomický výzkum a doktorské studium)

ISBN 978-80-7344-129-6 (Národohospodářský ústav AV ČR, v.v.i.) 


\title{
Determinants of Secondary School Choice in the Czech Republic ${ }^{*}$
}

\author{
Lenka Drnáková \\ CERGE-EI ${ }^{\dagger}$
}

\begin{abstract}
The admission process into secondary schools in the Czech Republic involves high risk of ending up at an undesired school if failing to be admitted to one's preferred school. Hence, the application decision is an important element of the process since individuals have to assess their chances of being admitted. Empirical evidence based on pupils participating in the PISA project suggests that especially the education of parents and cognitive abilities matter to a large extent for a pupil's application decision. Noncognitive skills are found to have an impact on a pupil's decision as well, even though the significance and magnitude differ across districts, and, most importantly, genders. Non-cognitive skills of females operate in accordance with intuitive expectationshigher risk associated with the outcome of the admission process in the district increases the importance of non-cognitive abilities with respect to decision-making. The opposite, counter-intuitive outcomes are obtained for males. Explanation and research suggestions are offered.
\end{abstract}

\begin{abstract}
Abstrakt
Prijímací proces na stredné školy sa vyznačuje vysokým rizikom, že žiak skončí na málo kvalitnej a neželanej škole v prípade, že neobstojí na prijímacom konaní na preferovanej škole. Rozhodnutie o tom, kam si žiak podá prihlášku je teda klúčové a žiak pri ňom musí čo najlepšie odhadnút' svoje šance na tej ktorej škole. Empirické výsledky tejto práce, založené na údajoch z PISA výskumu, naznačujú, že vzdelanie rodičov a kognitívne schopnosti sú hlavnými faktormi ovplyvňujúcimi vol'bu žiaka. Nekognitívne, osobnostné, schopnosti majú taktiež vplyv, aj ked' menší oproti predchádzajúcim faktorom. Čo je dôležité, vplyv týchto osobnostných charakteristík je iný u dievčat ako u chlapcov. Kým nekognitívne schopnosti dievčat majú vplyv v súlade s intuitívnymi očakávaniami, t.j. s rastúcou rizikovost’ou ich význam na rozhodnutie o vol'be školy rastie, u chlapcov tomu tak nie je. V článku sú rozobraté potenciálne príčiny a sú navrhnuté podnety pre d’alší výskum.
\end{abstract}

Keywords: non-cognitive skills, schooling choice, secondary education JEL Classification: J24, I21

\footnotetext{
* I would like to thank Professor Jan Hanousek for supervising this research project. I also thank Stepan Jurajda, Daniel Munich, Randall Filer, Libor Dusek and Evzen Kocenda for valuable comments and suggestions. I am grateful to Daniel Munich for providing me with data and especially for his inquiry that enabled linking the two datasets used in this work. Financial support from GAČR grant No. 402/06/1293 is gratefully acknowledged. I would also like to thank Richard Stock and Sarah Peck for editing the paper. ${ }^{\dagger}$ A joint workplace of the Center for Economic Research and Graduate Education, Charles University, Prague, and the Economics Institute of the Academy of Sciences of the Czech Republic. Address: CERGE-EI, P.O. Box 882, Politických vězňů 7, Prague 1, 111 21, Czech Republic. Email: lenka.drnakova@cerge-ei.cz
} 


\section{INTRODUCTION}

It is generally accepted that cognitive skills, i.e., thinking and reasoning abilities, most often represented by IQ scores, determine many economic outcomes, such as schooling or wages. On the other hand, until very recently, the role of non-cognitive skills, i.e., personality traits such as motivation, persistence, time preference, self control, patience or temperament, has not been explored much. Intuitively, noncognitive abilities should be important. For example, time preference and persistence may influence pursuing costly decisions rewarded in the distant future. Self confidence may affect pursuing risky actions with high return in exchange for losing opportunities with more certain outcomes. Evidence about non-cognitive skills having a significant impact on many labor outcomes as well as on a variety of risky behaviors is documented by Heckman, Stixrud and Urzua (2006).

It is likely that non-cognitive skills would matter in an environment in which access to a particular action is conditioned on a sequence of decisions that do not have to be solely associated with cognitive abilities, even though the final rewards from that action may depend on cognitive abilities only. The process of admissions to high schools in the Czech Republic, is a very good example of such an environment. Applicants may apply only to one school in the first round after which most of the slots at better schools are filled. Applicants to the most demanded secondary type of school, academic high schools, have to, in most cases, take an entrance exam. Failure on the exam implies a non-negligible probability that the applicant will end up in the lessdemanded, low-quality types of secondary schools. Hence, the application decision is an important element of the process, since individuals have to strategically assess their chances of being admitted. This decision is affected not only by cognitive abilities, but also by non-cognitive skills that characterize individuals' abilities to deal with uncertainty and incomplete information, such as self confidence, ability to perform under pressure, or attitude towards risk. Both types of skills are likely to determine an individual's assessment of her or his own chances as compared to others.

In this paper I examine the importance of cognitive and non-cognitive abilities with respect to the secondary school application decision in the Czech Republic. I suppose that cognitive skills may be inferred from tests measuring knowledge and 
skills in mathematics, problem solving, reading literacy and science. Non-cognitive skills in this analysis will be represented by scores on test items in two psychological scales assessing an individual's self-esteem and self-control. The Rosenberg SelfEsteem Scale measures an individual's perception of a person's overall evaluation of his or her worthiness as a human being. The Rotter Locus of Control Scale represents the degree of control individuals think they have over their lives. Indeed, I focus on only two of many types of non-cognitive skills. However, both self-esteem as an evaluation of one's self-approval and self control as a perception of the extent of control over one's life may be thought of as representing the level of self-confidence and belief in one's own skills to achieve something in life. These characteristics are likely to be very important in an uncertain admission process to secondary schools in the Czech Republic, even though, e.g., attitude towards risk may also be relevant. Unfortunately, the survey does not contain any reliable measure of attitude towards risk.

There are three types of Czech upper-secondary school programs: academic high schools, vocational schools and apprenticeships. These are ordered from the highest to lowest difficulty of being admitted, and from the most to least suitable for subsequent studies in universities. Graduates from the first two types of schools mostly finish with a general certificate examination $(\mathrm{GCE})^{1}$ that qualifies them to apply to universities. Graduates from academic high schools do not attain practical skills that would make them ready to occupy specific professions unlike graduates from the other two types. On the other hand, they have much better chances of being admitted to university. Vocational schools and apprenticeships are oriented towards providing skills for specific occupations, but while the former represents a complete form of secondary education, the latter usually does not. Apprentice programs provide manual skills for manual professions and they represent the worst form of secondary education with respect to chances for further studies even though some of them grant a GCE. ${ }^{2}$ These facts imply that there are likely to be two types of decisions in place for elementary school graduates. Some will decide between applying for an academic high school and a

\footnotetext{
${ }^{1}$ A very small share of vocational school programs do not provide the GCE. In 2003/2004, out of all newly admitted vocation school students, only $1 \%$ were enrolled in programs that didn't conclude with the GCE.

${ }^{2}$ In $2003 / 2004,16 \%$ of newly admitted students to apprenticeships were enrolled in GCE programs. This number is not negligible; nevertheless, it is unusual for those from apprentice programs to apply for tertiary education.
} 
vocational school. Others will decide between a vocational school and apprenticeship. ${ }^{3}$ I explore data for a sample of 15 year-old pupils in their $9^{\text {th }}$ year of elementary education who participated in the PISA 2003 survey. Among other things, these pupils were asked about their secondary school application choice. The analysis is done separately for males and females, to infer sex differences. This distinction is motivated by other studies that find gender differences in skills' impact on various outcomes, e.g., Heckman, Stixrud, Urzua (2006). The results suggest that parental education and cognitive skills significantly affect the decision of pupils. Non-cognitive skills have a significant, though weaker impact as well, especially for decisions of girls. I analyze the impact of all explanatory factors across districts that are characterized by different riskiness of admission process, represented by demand-supply discrepancy of individual school types. The observed results for girls are in accordance with intuition. For example, for fixed background characteristics, the probability of a girl applying to an academic high school decreases as the district measure of admission risk increases. However, the opposite outcome is obtained for boys, which is counter-intuitive. There are more outcomes for boys that are not intuitive. Potential underlying causes are discussed.

The paper is organized as follows: the next section summarizes the evidence on the role of non-cognitive skills in the literature and describes how this concept may fit into a schooling choice framework. Section 3 describes the system of secondary schools in the Czech Republic. In section 4, an estimation framework is introduced. Section 5 contains a detailed data description. The results of a standard probit analysis are provided in section 6. Section 7 introduces an alternative way to estimate the probabilities of choosing academic program/apprentice program. Section 8 summarizes the outcomes and discusses the possible implications.

\footnotetext{
${ }^{3}$ This is partially confirmed by examining information provided by the parents of those pupils who are already enrolled in the first year of a secondary program (i.e., those who are excluded from the sample used in this paper). The parents were questioned about their satisfaction with the type of school attended by their child. Most of those not satisfied with their child attending an apprenticeship without the GCE wish their child would attend a vocational school. Similarly those not satisfied with their child attending a vocational school mostly wish their child would attend an academic high school.
} 


\section{SCHOOLING CHOICES AND THE ROLE OF NON-COGNITIVE SKILLS - EXISTING LITERATURE}

Literature on school choice in the Czech Republic provides consistent evidence that background characteristics are important determinants of educational outcomes. Munich (2004) estimates academic high school admission probabilities when he deals with the question of differences in performance among students from different types of secondary schools. As a result, from a first stage selection equation he finds that in addition to skills, measured by grades in Czech language and mathematics, and education of parents, local schooling supply conditions are also important determinants of academic high school enrollment. Knot and Munich (2006a, b) elaborate on the secondary school application choice in a matching framework and suggest that education of the parents and family income are significant predictors of education choices of a child, so that the social gaps are not diminishing, but rather staying stable as an outcome of the admission system. There is a larger amount of sociologic literature dealing with access to education, especially among students from lower social backgrounds. Burdová, Matějů, and Procházková (2004) emphasize the fact that children with poorer backgrounds do not even consider submitting an application for some forms of tertiary education. This applies also to those whose results on the tests of general study predispositions are better than those of children from better situated families who apply to university.

Evidence on the importance of background characteristics is also present in papers dealing with educational choices in Germany. In Germany, similarly as in the Czech Republic, the choice of secondary education is important and predetermines the future career of an individual to a large extent. University education in Germany is specific in the sense that only the graduates from the highest secondary track schools are directly eligible to access universities. The secondary school decision is made even by the age of 10 . The decision is the result of parental choice and the primary teacher's recommendation; there are no entry tests. Therefore, there is almost no uncertainty associated with the decision. However, Dustmann (2003) points to intergenerational immobility in educational achievements and relates it to parental characteristics: education, preferences, confidence and tastes. He also does not exclude the possibility that a child of highly educated parents also has potentially higher learning capabilities. 
Background characteristics are, according to Cunha et al. (2005), essential for the development of both cognitive skills and non-cognitive skills. While the former are generally acknowledged to affect labor market outcomes, the latter are likely to have an impact on decisions too. For example, recent U.S. evidence by Heckman, Stixrud and Urzua (2006) suggests that non-cognitive abilities determine the level of subsequent schooling. This way, indirectly, non-cognitive skills affect productivity and wages, even though their direct impact is not confirmed, unlike the impact of cognitive skills. Another stream of literature addresses the role of non-cognitive skills to explain why children from worse social backgrounds do not pursue better education. Cunha et al. (2005) claim that financial constraints play a minor role and offer a different explanation. They suggest that a poorer background is associated with difficult access of children to better (primary and) secondary schools, a better living environment, or motivating "role models" represented by their parents, and these are primary reasons why these children do not develop sufficient skills to pursue further education. ${ }^{4}$ While access to better primary schools is generally not constrained in the Czech Republic, other constraints associated with a poorer background apply. Also, taking into account uncertainty of the admission process into secondary schools in the Czech Republic, noncognitive abilities, such as self-esteem may be important with respect to applications to more demanded schools. As claimed by Knot and Munich (2006), pupils, especially students from lower social backgrounds exhibit a tendency to apply to a different type of school than the one they actually desire. This paper shows that the level of noncognitive skills plays a role (for females as long as applications to academic high schools are considered and for decisions of both genders as long as applications to apprenticeship programs are considered) and hence may affect the extent of misrepresentation of preferences.

\footnotetext{
${ }^{4}$ Evidence that financial constraints are not the only obstacle for students with socially disadvataged backgrounds is documented by Cameron and Heckman (1999). They examine recipients of President Clinton's Hope Scholarship funds, targeted to promote better access to higher education to students coming from low income families. They find that financial constraints do not represent the main reason why these students do not promote higher education. Their estimates suggest that an enormous fraction of funds $(93 \%)$ was obtained by children who would have attended school anyway, i.e., even without the program.
} 


\section{THE CHOICE OF SECONDARY SCHOOLS IN THE CZECH REPUBLIC AND THE CONSEQUENCES OF THE CHOICE}

There are three types of secondary education in the Czech Republic. Academic high schools, attended approximately by $20 \%$ of a cohort, provide general education that is best suited for university entry tests. The other two types of secondary schools are both attended by around $40 \%$ of adolescents and are more practically oriented. Apprenticeship programs last from 2 to 4 years and prepare students to enter manual professions. Vocational schools are 4-year programs and prepare students for specific labor market professions, such as nursing or engineering. While academic high schools and the bulk of vocational schools finish with a general certified exam, most apprentice programs provide their graduates with a vocational certificate. Since only those students who finished secondary school with the GCE are eligible for university studies, those attending apprenticeships without a certified exam cannot apply for tertiary education.

Each school administers its own admission procedure. It is usual that better schools hold entrance tests. This applies to almost all academic high schools and also to a part of vocational schools. Applications are submitted in advance. In 2002/2003, pupils in the $9^{\text {th }}$ year of elementary school might submit two applications to public schools, one as the choice for the first round and one as the choice for the second round. They might also apply to an unconstrained number of private secondary schools. In the first round of the admission process, some pupils were admitted to their first choice schools. Those who were not, participated on the second round of the admission process accordingly to their second choice. However, once the places at the school of second option were already taken, a pupil had to wait for places remaining after the second round and might end up at an undesired school. Private schools served especially as outside options for those who could afford it. From 2004/2005, some changes were introduced into the system; however uncertainty associated with decision still remains.

The choice of the type of the secondary school in the Czech Republic largely predetermines future career outcomes. According to the Institute for Information on Education, $93 \%$ of academic high school graduates achieve at least some type of higher education. The shares of those applying for universities are $91 \%, 50 \%$ and $27 \%$ of graduates from academic high schools, vocational schools and apprenticeships, respectively. The shares of those enrolling in universities are $58 \%, 18 \%$ and $10 \%$, 
respectively (Munich, 2004). ${ }^{5}$ Finally, individuals with university education in the Czech Republic earn significantly more than those with lower education. The returns to education is about $30 \%$ higher for people with university education. ${ }^{6}$

In summary, the selectivity of the education system in the Czech Republic that starts with the choice of secondary education has a large degree of persistence and subsequently results in significant differences in wages. The choice of secondary school is likely to be affected by both parents and their child since at the time of this decision children are 15 . However, features of the admission process to secondary schools are such that the choice is likely to also depend on factors other than background characteristics or cognitive skills of a child. Non-cognitive abilities such as self confidence are likely to play an important role.

\section{EMPIRICAL SPECIFICATION OF AN INDIVIDUAL'S SECONDARY SCHOOL APPLICATION DECISION}

The outline of a theoretical utility maximization framework that describes the decision process of a pupil and that introduces the factors important for the school type choice can be found in the Appendix. These factors include variables describing a pupil's background. In particular, I account for dummies indicating attained education of parents - less than secondary education with GCE, complete secondary and tertiary education. I also include income per family member to account for two possible effects of income on a pupil's decision. The first effect of income relates especially to the choice of academic high school. Since this school type primarily serves to prepare students for further studies at university, those who choose it choose not to earn a salary

\footnotetext{
${ }^{5}$ Enrollment rate in general is very low. According to the OECD report "Education at a Glance 2005," the fraction of the Czech population with tertiary education ranges from $11 \%$ (age group $45-54$ ) to $15 \%$ (age group 35-44) with an average of $12 \%$ (age group 25-64). Total enrollment in tertiary education has grown by $70 \%$ since 1995 ( $74 \%$ if one does not consider the change in population). In 2003 , the entry rate into tertiary education amounted to $33 \%$ of the population (tertiary education type A), which is actually the lowest number among all European OECD members.

${ }^{6}$ Under communism, an individual's attained level of education played a relatively small role with respect to earnings. This changed with the change of political system. Education is now a major factor contributing to wages. Its role increased dramatically in the early period of transition. Returns to a year of education were $2-3 \%$ at the beginning of transition while they reached $6-9 \%$ by the end of the $1990 \mathrm{~s}$ (Munich, Svejnar and Terrel, 2005; Campos and Jolliffe, 2003).
} 
for 7 and more years. ${ }^{7}$ Hence, a child from a wealthy family that is able to support him/her during studies would more likely apply to an academic high school. On the other hand, low earning parents may want their children to get ready for the labor market faster, pushing them to apply for labor market oriented apprenticeships or vocational programs. The second effect of family income is associated with a pupil's back-up option in form of enrolling in a private school in the case of failing admission to a public school. Hence, a pupil from a family with higher income can consider the decision to apply to a highly demanded school less risky since he/she has an affordable alternative in the form of a private school. In 2003, private schools were not part of the classic admission process, i.e., pupils might apply there without constraints. Admissions to private schools were separated from admissions to public schools and enrollment was mostly conditioned only on paying tuition. In my estimations, I also include a pupil's skills, both cognitive and non-cognitive and examine their impact. For non-cognitive skills I can only use data from two psychological scales measuring self-esteem and selfcontrol of respondents. It would be useful if a measure of risk aversion would be available as well, however the PISA survey does not contain items addressing risk aversion. Because the effect of skills, and potentially of other explanatory variables, is likely to change with the local characteristics of a district, a variable capturing district supply-demand conditions is included. In this paper, I define this variable as excess demand for a specific school type to reflect the difficulty of being admitted to that particular school type in any district. The construction of this variable is described in detail in the next section.

Importantly, given the different characteristics of academic programs, vocational schools and apprenticeships, it is likely that utility associated with apprenticeships would be very low for an individual seeking a general certificate (i.e., complete secondary education) or even higher education. On the other hand, for pupils with (cognitive and/or non-cognitive) skills at the bottom part of the population distribution, utility associated with an academic high school would be very low since the study aptitude requirements at academic high school would not be matched with their skills. Therefore, it is probable that one group of pupils would actually make a decision

\footnotetext{
${ }^{7}$ This applies to those in the $9^{\text {th }}$ grade of elementary school. Academic high school lasts 4 years and tertiary education lasts at least 3 years.
} 
between an academic high school and a vocational school and the other group of pupils would decide between applying to a vocational school or an apprentice program. To estimate the probabilities of applying to an academic high school (apprenticeship), I use a standard probit model. I assume linear-in-the-parameters specification. Let $\boldsymbol{V}$ denote a total benefit associated with the application to an academic high school (apprenticeship):

$$
\begin{aligned}
& \boldsymbol{V}=\alpha+\beta^{1 m} \boldsymbol{E} \boldsymbol{D} \boldsymbol{U}_{\mathrm{sec}}^{m}+\beta^{2 m} \boldsymbol{E D} \boldsymbol{U}_{\text {ter }}^{m}+\beta^{1 f} \boldsymbol{E} \boldsymbol{D} \boldsymbol{U}_{\mathrm{sec}}^{f}+\beta^{2 f} \boldsymbol{E} \boldsymbol{D} \boldsymbol{U}_{\text {ter }}^{f}+\beta^{\text {inc }} \boldsymbol{I N C} \\
& +\beta^{E D} \boldsymbol{E} \boldsymbol{D}^{D}+\beta^{C} \widetilde{\boldsymbol{f}}^{C}+\beta^{N} \tilde{\boldsymbol{f}}+\boldsymbol{E} \boldsymbol{D}^{D}\left[\gamma^{2 m} \boldsymbol{E} \boldsymbol{D} \boldsymbol{U}_{\mathrm{sec}}^{m}+\gamma^{2 m} \boldsymbol{E} \boldsymbol{D} \boldsymbol{U}_{\text {ter }}^{\boldsymbol{m}^{N}}\right. \\
& \left.+\gamma^{1 f} \boldsymbol{E D} \boldsymbol{U}_{\mathrm{sec}}^{f}+\gamma^{2 f} \boldsymbol{E} \boldsymbol{D} \boldsymbol{U}_{\text {ter }}^{f}+\gamma^{i n c} \boldsymbol{I N C}+\gamma^{C} \tilde{\boldsymbol{f}}^{C}+\gamma^{N} \tilde{\boldsymbol{f}}^{N}\right]+\boldsymbol{e}
\end{aligned}
$$

where $\boldsymbol{E D} \boldsymbol{U}_{i}$ stands for educational background of parents (a dummy for secondary and tertiary level attained as the highest level of education), family income is denoted by $I_{N} C_{i}, E D^{D}$ characterizes district excess demand for places at academic high school (excess supply of apprenticeships) and $\tilde{\boldsymbol{f}}^{C}, \tilde{\boldsymbol{f}}^{N}$ represent measures of cognitive and non-cognitive skills. Since the effects of skills are likely to vary with varying demandsupply structure in a district, I include interaction effects of excess demand (excess supply) with cognitive and non-cognitive skills. Specifically, with increasing excess demand for a given school type there is more uncertainty as to whether one would be admitted. Hence, non-cognitive skills, such as self-confidence, should affect application decision more and cognitive abilities should matter less in high uncertainty environment. Other interaction effects of background variables and excess demand are included for consistency reasons as well, even though there are no intuitive reasons for this inclusion.

Application to an academic high school (apprenticeship) is reflected in binary variable $\boldsymbol{G}=1(\boldsymbol{A}=1)$ if $\boldsymbol{V}>0$. Error component $\boldsymbol{e}$ is assumed to be independent of explanatory variables.

\section{DATA DESCRIPTION}

In this section, I focus on describing the factors that are likely to influence the choice of secondary school. I explain the construction of the measures of cognitive and 
non-cognitive skills and depict their sample distributions according to the choice of the secondary school of pupils. I provide basic information on the education of parents and family income for the sub-samples of pupils sorted according to their school choice. Basic statistics for these variables can be found in Table 5.1 in the Appendix.

I also describe the supply of (and revealed demand for) individual school types across districts in the Czech Republic in 2002. Since the measure of revealed demand is not likely capturing true demand, because pupils strategize their choice based on available information, I predict demand based on district characteristics. Based on predicted values of demand, I construct the measures of excess demand for academic high schools and excess supply of apprenticeships in the district. These measures should capture the difficulty of the admission process in the districts.

\subsection{Cognitive and non-cognitive skills}

To measure cognitive skills, the results on mathematical, problem solving, reading and natural science tests from PISA 2003 are used. Only a small fraction (7.5\%) of children participated on all 4 types of the tests. All students participated in the math test. In order to use as much information as possible from these tests and give it a plausible interpretation, I construct a variable that reflects a standardized average based on the tests participated in. By non-cognitive skills, I consider the combination of the level of self-esteem and self-control, as these are implied by the answers to the subset of questions belonging to the psychological Rosenberg and Rotter scale. Similarly as in the case of cognitive skills, I use a standardized average to describe the level of an individual's non-cognitive skills (based on the psychological scales pupil had completed). ${ }^{8}$

The sample distribution of cognitive skills of males is different from that of females (see Figure 5). Female distribution is more tightly concentrated around the mean. More males than females achieve exceptionally high scores. The distribution of non-cognitive skills of males is shifted slightly to the right of the female distribution,

\footnotetext{
${ }^{8}$ It is important to note that standardization is based on the whole sample of those in the $9^{\text {th }}$ grade of elementary school. However, data on education or income of parents are available only for a sub-sample. Distributions of cognitive and non-cognitive skills of those in a sub-sample with no information on the education/income of parents are slightly to the left of the sub-sample used in analysis. As shown also in Table 5.2, the skills of pupils included in the analysis are above the average of the whole sample (the average of a standardized variable is 0 ).
} 
hence on average males achieve higher scores on scales measuring non-cognitive abilities.

Figures 5.2 and 5.3 depict the sample distributions of both types of skills based on a school type that pupils applied for in the first round of the admission process. The distribution of cognitive abilities of both males and females applying for apprenticeships is located to the left of the cognitive skills' distributions based on those applying to vocational schools and academic high school. The female sample distributions are more concentrated. In other words, female pupils apply to school types more consistently with respect to their cognitive skills than males. The distributions of non-cognitive skills are less different across application choices, compared to the distributions of cognitive abilities. Yet, the sample distribution of non-cognitive skills for males applying to academic high schools quite corresponds to the one for males applying to vocational schools (see also Table 5.2 for means and standard deviations of the distributions).

In summary, it seems that girls with better skills (of both types) are more likely to apply to academic high schools and girls at the lower end of both distributions apply for apprenticeships. Considering cognitive and non-cognitive skills, boys sort themselves to school types less predictably, and there seem to be other potential factors which are likely to play a role in their decision.

\subsection{The role of parental background}

Figures 5.4 and 5.5 display the percentages of pupils, sorted accordingly to their secondary school choices, whose mothers and fathers achieved, respectively, up to the secondary level of education without a general certified exam, a complete secondary education (with GCE), and a tertiary level of education. Clearly, children of university educated parents apply more frequently to academic high schools and children of lower educated parents apply more frequently to apprenticeships. Compared to boys, the daughters of low educated mothers more frequently apply to apprenticeships. On the other hand, once their mother has a secondary degree with GCE, girls are less likely to apply to secondary schools without a GCE and apprenticeships compared to boys. The share of boys applying to academic high school programs with a tertiary educated mother is higher than the corresponding share of girls. With respect to fathers' 
education, the general outcomes valid for the education of mothers hold, even though the differences between boys and girls are less pronounced when applications to apprenticeships are considered. Out of those applying to academic high schools, $46 \%$ of boys have a father with a tertiary degree as compared to $36 \%$ of girls.

The last individual background factor is family income per member, computed as total family income stated in a survey divided by the weighted sum of adults and children in a household, with children given the weight of $1 / 2$ and adults given the weight 1. Means and standard deviations of this per-capita income for sub-samples of boys and girls sorted according to the choice of education are displayed in Table 5.3. It is evident that on average, children applying to higher quality schools come from families with higher income. More girls than boys applying to academic programs and vocational schools come, on average, from families that have a lower income.

\subsection{Secondary schools across districts: supply and demand}

As outlined in the introduction, the ratio of slots in academic high schools to all slots in secondary schools is only around $20 \%$. Also, out of a cohort of elementary school pupils that participated in PISA, 20\% ended up at 4, 6 or 8-year academic programs. This ratio varies across districts. It is important to notice that for pupils in the $9^{\text {th }}$ grade, only a portion of these places are available, since some academic high school places are already taken by pupils studying in 8- or 6-year academic programs (see Figure 5.6). The shares of slots at each type of school that are available to 9th grade elementary students are depicted in Figure 5.7.

However, with respect to an individual's choice of education, not only supply matters. What is more important is the demand for school types, or more precisely, the difference between the demand and supply that captures how difficult (or easy) it is to get into a particular school in a given district. While the supply of places in a school is fixed and pupils know it in advance, the demand is observed after applications are submitted. Pupils have an indication about the demand for individual schools in the form of data from previous years. They can also infer some information from the intended decisions of their peers. Because individuals assess their chances and strategize their choice in order not to end up at an undesired school, revealed demand within a district is already a result of this strategizing and can be very different from the true 
underlying demand. Therefore I measure demand for particular school types as it would be expected based on its environment. The district-specific conditions that should determine applications to specific school types include, for example, the educational structure of the population in a given region, the presence of university or labor market characteristics, such as unemployment rates. Therefore, I rather predict demand based on environmental characteristics of a district.

As a determinant of true demand for academic high schools, I use the following explanatory variables: the share of tertiary educated population to proxy for education of parents in a given district, a dummy variable indicating the presence of a public university in a district to account for proximity and hence affordability of tertiary education in the future and the share of places at the academic high school not taken by students in 6- and 8- year academic high school programs. Intuitively, given the same share of tertiary-educated population in the two districts and different shares of longerthan-4-years academic programs, bidding for academic high school places should be higher in a district where availability of these places for $9^{\text {th }}$ graders is higher. As supposed, the share of population with university education is a significant positive factor in predicting demand for academic high schools (see Table 5.4). Similarly, as expected, districts with a higher share of academic program places still available for students in the $9^{\text {th }}$ grade display a higher demand for such places. Finally, the presence of a university has a small negative effect on demand, but this may be only the result of the small number of districts with university.

Considering the choice of apprenticeship vs. vocational school, I estimate true demand for apprenticeships using the share of the population with education without GCE in the district. The coefficient is almost equal to one; hence, a one percent increase in the share of the population with at most incomplete secondary education is associated with a corresponding one percent increase in a predicted demand for apprenticeships (see Table 5.5). ${ }^{9}$

\footnotetext{
${ }^{9}$ When predicting demand for academic high schools (apprenticeships) I also included other explanatory variables, such as the presence of a private university in the district, the presence of an upper vocational school, the share of population living in cities, unemployment rates according to education status and unemployment rates- total and partitioned according to the education of the unemployed. However, these determinants are not significant and including them does not change the predictions of demand.
} 
From both regressions I obtain fitted values that define predicted demand for academic high schools (apprenticeships) as expected based on environmental features in the district. I subtract the supply of academic high schools from the predicted demand and obtain a measure capturing the discrepancy between predicted demand for academic high schools and their supply. Similarly, I subtract expected demand for apprenticeships from their supply to obtain the measure of discrepancy in demand for apprentice programs. These measures are very different from the measures of excess demand one would obtain directly from revealed demand and supply numbers (see Figures 5.8 and 5.9). These measures characterize the district from the point of ease or difficulty of being admitted once one has applied to a specific school type. As such, they also represent the level of risk associated with the admission process. In particular, high excess demand for academic high schools, associated with high difficulty of being admitted, should also be associated with higher risk of ending up at an undesired, low quality school. High excess supply of apprentice programs in the district is likely to be associated with more variety of apprentice programs. Therefore, in the case of failure after applying to a presumably higher quality vocational school in such a district, pupils have higher chances to find an appropriate, even though possibly not particularly desired, apprentice program.

\section{EMPIRICAL ANALYSIS OF APPLICATION CHOICE DETERMINANTS}

\subsection{Determinants of academic high school choice}

To look broadly at the role of cognitive and non-cognitive skills, in Table 6.1, Column 1 and 4, I display the basic results of a model of academic high school application choice that does not include interaction effects between measures of excess demand and other explanatory variables. For better interpretation, instead of coefficients, I report the marginal effects of the variables at the mean values of remaining variables. Since income and skill measures are standardized, the marginal effects comparatively capture the magnitude of a one-standard-deviation increase in these variables. The marginal impact of cognitive skills is significant in both specifications, and noncognitive skills significantly predict the choice of girls, even though the magnitude of the effect is much lower. For both genders, both types of skills are jointly significant. 
The effect of excess demand is insignificant for both boys and girls, even though it has the expected negative sign. In Table 6.1, Columns 2,3,5,6, I report the results for parsimonious specifications of the model, one without variables capturing skills, the other without variables capturing the education of parents, hence providing upper bounds on the estimated effects of skills vs. education. The outcomes suggest that both skills and parental education affect the choice of a child since deleting either skills or education from the equation leads to higher estimates of education or skills. The education of parents has therefore a direct effect on application, likely in the form of "pushing" a child to a particular school. Also, the skills of a pupil, even though at least partially determined by the education of parents, have a direct effect on his/her choice. The coefficient on income increases as well when education dummies are not included which is a reflection of correlation between education and income. I return to the direct and indirect effect of skills vs. education in the next section.

However, it is likely that the impact of skills, and potentially also the impact of the background variables will be different across districts. Specifically, districts are characterized by different demand-supply conditions- with increasing excess demand for a given school type there is a higher risk associated with admission. Non-cognitive skills, such as self-confidence, should affect application decision more and cognitive abilities should matter less in more uncertain environment. Hence, in the next specification I include the interaction effects. Estimated coefficients and their significance are displayed in Table 6.2. ${ }^{10}$ However, information included in this table is only limited. (The problem is that the coefficients on simple and interaction effects are not the marginal effects.) One has to evaluate derivation of interest and compute standard errors. As pointed by Norton, Wang and Ai (2004), in the case of interaction terms, evaluating a cross-partial derivative with respect to both variables leads generally to different signs of marginal effects for different values of covariates and to different significance. A similar issue is in place if the same variable is included in several interaction terms, as in the case of a variable capturing excess demand that is interacted with background characteristics and skills.

\footnotetext{
${ }^{10}$ I also estimate a linear probability model as a check for the distributional assumptions of the probit model. Coefficients and standard errors from the regression do not differ much from the marginal effects at mean values of variables. This suggests that assumptions on the distribution of conditional probability are appropriate.
} 
Therefore, to assess the magnitude and significance of interaction effects, I compute marginal probabilities and corresponding z-statistics for excess demand at the $10^{\text {th }}, 25^{\text {th }}, 50^{\text {th }}, 75^{\text {th }}$ and $90^{\text {th }}$ percentile, separately changing values of income, cognitive skills and non-cognitive skills, fixing remaining factors at their means, assuming that both parents have attained secondary education. I also examine how the change in attained education of both parents from a secondary degree to tertiary degree affects the probability of applying to an academic high school, fixing both types of skills and household income at their mean values.

Figures 6.2a)-d) and 6.3a)-d) display the marginal effects of background variables on academic high school application probability alongside with z-statistics for five levels of excess demand. The marginal impact of family income on the tendency of males to apply (Figure 6.2a) is insignificant (both economically and statistically) in districts with high excess demand (the $75^{\text {th }}$ and $90^{\text {th }}$ percentile of a distribution). On the other hand, in districts with low or negative values of excess demand, the marginal increase in family income has a positive effect on the probability of applying, but only at lower levels of per-capita family income (for high-income families, the effect is statistically insignificant). The magnitude of this effect decreases with increasing excess demand (increasing risk), but the differences are very small. For females, the marginal effect of household income is completely insignificant (see Figure 6.3a).

Regarding the role of education of the parents, the probability of a male applying to an academic high school when both parents have a tertiary degree increases by $22 \%$ compared to when both parents have a secondary degree (at the 50th percentile of excess demand for academic high schools). The magnitude of the effect decreases with higher excess demand (higher risk), with a difference of around $8 \%$ between the $10^{\text {th }}$ and $90^{\text {th }}$ percentile of excess demand (see Figure 6.3b) For females, the marginal effect of parental education is significant in districts with excess demand around the $50^{\text {th }}$ and $75^{\text {th }}$ percentile, however it is not significant for lower as well as higher levels of excess demand (see Figures 6.3b). The magnitude of the effect is small for females, amounting to around $6 \%$ increase in female academic high school application probability when their parents attained tertiary education as when they have a secondary education attained only. 
In summary, the role of family income in predicting the probability of applying to academic high schools is very small and does not change much across dFistricts. The effect of tertiary education is much larger, and that applies especially to boys. For girls, it is lower and insignificant at some level of excess demand. However, the main focus of this paper is the role of cognitive and non-cognitive abilities. The next two paragraphs summarize the findings.

An increase in cognitive skills by one standard deviation has a positive and significant impact on the probability of males applying to academic high schools in all districts except for those with the lowest values of excess demand for academic high schools. When moving from the lowest to the highest levels of cognitive skills, the magnitude of the effect increases (see Figure 6.2c). The magnitude of the effect is higher also in districts with higher excess demand, which means that the role of cognitive abilities in application probability becomes more important as the application process becomes riskier. This is a counterintuitive outcome and I will elaborate on possible causes of this outcome below. For females, the marginal effect of cognitive skills is significant and it is stronger than for males. Excess demand in a district has a negative impact on the magnitude of the effect, especially for moderate levels of cognitive abilities. In other words, with increased risk in the application process, the role of cognitive skills becomes weaker (see Figure 6.3c).

The effect of non-cognitive skills is insignificant for males at all levels of excess demand for academic programs (see Figure 6.2d). For females, non-cognitive skills are statistically unimportant when excess demand for academic high schools is low, hence the risk of ending up at an undesired school in the case of failing the academic high school application process is low (see Figure 6.3d: the $10^{\text {th }}$ and $25^{\text {th }}$ percentile of the excess demand distribution). In districts with larger values of excess demand, the effect of a one-standard-deviation increase in non-cognitive skills is positive and significant, but only at smaller levels of non-cognitive skills. More importantly, the magnitude of the effect is highest in districts where the difficulty of being admitted is the highest. This is in accordance with the expectations that non-cognitive skills (in this case possibly referred to as self-confidence) would become more important in a riskier environment. 
The marginal effects and their significance provide information about the importance of the explanatory factors; however, in order to understand the character of their effect better, it is useful to simulate the predicted probabilities of application to academic program. In the following, I focus on the role of cognitive and non-cognitive skills, since the results so far show some interesting differences between females and males. I fix the standardized income at the mean level (of the whole sample of pupilsall school type choices) and I fix education of both parents at the secondary level. For the $25^{\text {th }}, 50^{\text {th }}$ and $75^{\text {th }}$ percentile of cognitive (non-cognitive) skills, I compute the probability of applying to an academic high school, while fixing non-cognitive (cognitive) skills at their mean values and moving across districts with different values of excess demand. The general expectation is that for two pupils with the same characteristics, the probability of application to an academic program should be lower for the one coming from a district with high excess demand.

Figure 6.6a) displays the predicted probability of applying to an academic high school for fixed values of non-cognitive skills. The predicted probability of applying to an academic high school in the districts with higher difficulty of being admitted (captured by higher values of excess demand) is decreasing for females, which is in accordance with the hypothesis that increased riskiness of the admission process discourages students from applying. The difference between probabilities of applying for females at the $25^{\text {th }}$ and $75^{\text {th }}$ percentile of cognitive skills decreases, even though only slightly, as moving to districts with larger excess demand. On the other hand, the difference in application probabilities for females at the $25^{\text {th }}$ and $75^{\text {th }}$ percentile of noncognitive skills (with fixed cognitive skills at the mean) increases as excess demand increases (see Figure 6.6b). These observed facts are intuitively expected, as the measures of non-cognitive skills interpreted approximately as the level of selfconfidence should matter especially in a risky environment, at the expense of cognitive skills. For males, however, the results do not follow the intuition. First, the probability of applying increases with higher risk of being admitted (higher excess demand) at least for those with higher cognitive skills. Moreover, the level of cognitive skills becomes increasingly important with increasing excess demand and non-cognitive skills appear to play no role at all. Overall, the levels of probabilities for males and females are 
diametrically different, with the probability of a male applying to an academic high school being very low in comparison to a female with similar characteristics.

There are few explanations of this result. One states that vocational schools are generally a good alternative to academic high schools for boys, for instance because of the characteristics of the curriculum which is frequently technical. If districts with high excess demand for academic high schools also provide higher quality education of academic type, we would observe higher frequency of boys applying to academic high schools in these districts, with especially those highly skilled applying. Another explanation, possibly associated with the previous one, is that the different excess demand for academic high schools is driven by the chances to get to the universities later on (a potential measure of school quality). Then, boys aspiring for tertiary education, not discouraged by the technical orientation of many vocational schools, apply for them if their subsequent chances to get to university are comparable with those of academic high school graduates. Within this respect it should be stressed that especially graduates from engineering, electrotechnics, telecommunications and IToriented vocational programs continue on to tertiary education. The majority of these students are boys. On the other hand, students of nursing schools or schools providing economic and administrative skills, the majority of whom are girls, do not often continue with university education. ${ }^{11}$ There is a space for further research to elaborate on these explanations.

\subsection{Determinants of the choice of apprenticeship program}

To estimate the probabilities of applying to an apprenticeship program, I follow a strategy similar to the one I use for academic high school choice. As a variable measuring the discrepancy between supply and demand, I use the excess supply of apprentice programs in a district computed based on predicted demand for apprenticeships and their actual supply. I do not use a measure of excess demand for vocational schools, since it is more difficult to assess true demand for vocational programs based on the educational structure of the population than to assess demand for

\footnotetext{
${ }^{11}$ According to www.nuov.cz, in $2002 / 2003$, about $50 \%$ of graduates from engineering programs and around $70 \%$ of graduates from electrotechnics, telecommunications and IT programs applied for universities with high chances of enrolling (around $45 \%$ and $60 \%$ of graduates respectively). Graduates from building schools also have high chances of getting into a university.
} 
apprentice programs. Similarly, as in the case of academic high schools, Table 6.3 displays the results from the probit model without interaction effects. The role of both kinds of skills is statistically significant for both genders; the coefficients on cognitive skills are of greater magnitude than the coefficients on non-cognitive skills. For both genders, both types of skills are jointly significant. The effect of excess supply is significant only for males. It has a positive sign which suggests that the probability of applying for an apprenticeship is higher in districts with larger excess supply, i.e., in districts where the predicted demand for apprenticeships based on the educational structure of population, is much lower than actual supply. This is at odds with expectations, considering the likely variety (in quality and curriculum) of apprentice programs in the district with larger excess supply of apprenticeships. Hence, the risk of ending up at the really undesired school is lower in such districts than in the districts where excess supply is negative or low and hence, one would expect pupils to apply for vocational school (of presumably higher quality) more frequently. However, as it will be shown later, inclusion of interaction effects changes the outcomes significantly.

In the next specification I include interaction effects to see how the importance of background factors and skills change with varying excess supply of apprenticeships. Following the procedure used in estimating academic high school application probability, I fix the variable capturing excess supply of apprenticeships at the $10^{\text {th }}, 25^{\text {th }}$, $50^{\text {th }}, 75^{\text {th }}$ and $90^{\text {th }}$ percentiles, respectively. As outlined above, a measure of excess supply of slots at apprentice programs can be thought of as representing the level of risk associated with the admission process, so that a pupil should apply for vocational school more frequently if the supply (and variety) of apprenticeships is high. In that case, failing the vocational school admission process would likely lead to a relatively high number of remaining apprenticeship options. Given the level of discrepancy between demand and supply, I examine how the probability of applying to apprentice programs changes as respectively, income, cognitive and non-cognitive skills change, fixing other values at their means and assuming that both parents have attained secondary education. I also examine how having parents who attained the tertiary level of education influences apprenticeship application probability, compared to having parents who both attained the secondary level of education, fixing both types of skills and per-capita 
household income at their mean values. Graphical illustrations of marginal effects and their z-statistics are in Figures 6.4a)-d) (boys) and 6.5a)-d) (girls).

The marginal effect of family income on the probability of a boy applying for an apprentice program is negative. Its significance depends on the level of family income and on the level of excess supply in a district. Overall, when significant, the effect of family income is negative, small in magnitude and there are not important differences across districts (see Figures 6.4a). For girls, the effect is significant for moderate levels of excess supply in districts at moderate values of income. The magnitude of the effect that amounts up to $-1 \%$ only and decreases (in absolute value) with larger excess supply, and the differences are, similarly as in the case of boys, small (see Figure 6.5a).

The magnitude of the effect of parental tertiary education decreases with supply of apprenticeships for both genders but it is significant only for boys and only for low values of excess supply of apprenticeships. In other words, the effect is significant and largest when the application process risk is highest; when risk is lower (larger excess supply), education of the parents no longer affects the probability of boys applying to apprenticeships anymore (see Figures $6.4 \mathrm{~b}$ and $6.5 \mathrm{~b}$ ).

In summary, the results for apprenticeship application probability with respect to the role of income and education are similar to those obtained for academic high school probability. While family income has a minimum impact, the effect of tertiary education is much larger, nonetheless affecting male probability only. Now, let me summarize how the impact of cognitive and non-cognitive abilities changes with excess supply.

In general, for both males and females, the effect of cognitive skills on the probability of applying to an apprenticeship is significant for all but the highest values of cognitive abilities. The significance of the effect for females depends also on the level of excess supply- it is almost insignificant in districts with large excess supply (low risk associated with the admission process). At moderate levels of cognitive abilities, the magnitude of the effect is lower in districts with higher excess supply of apprenticeships (i.e., cognitive skills become less important as the risk associated with the admission process decreases). However, for females at the lowest levels of cognitive skills, a marginal impact of one standard deviation increase in cognitive skills is stronger in districts with lower risk of being admitted. Since most of the applicants to either vocational schools or apprentice programs are at the lower part of the cognitive 
skills distribution, it is clear that cognitive skills are of weaker importance as the risk goes up for females. The opposite is true for males. This suggests, again, the existence of some other factors influencing male choice in the risky application environment (see Figures $6.4 \mathrm{~b}$ and $6.5 \mathrm{~b}$ ).

Non-cognitive skills do have a significant effect on the male application probability when the supply of apprenticeships is large: the $50^{\text {th }}, 75^{\text {th }}$ and $90^{\text {th }}$ percentiles (see Figure 6.4c). The effect is significant at higher levels of non-cognitive skills only. The magnitude of the effect is low, and increases with higher excess supply. This means that lower risk of admissions strengthens the role of non-cognitive skills, which is not the outcome one would expect. For females, the effect of non-cognitive abilities is significant when apprenticeships' supply is not very low and not very high, and only at moderate and higher levels of non-cognitive abilities. The magnitude of the effect decreases with increasing excess supply (lower risk), which is, contrary to boys, an expected outcome since intuitively the role of non-cognitive factor should be stronger in a more uncertain environment (see Figure 6.5c ).

Similarly as for the probability of academic high school application, I simulate predicted probabilities of application. Within a complete range of values of excess supply, I focus on the role of cognitive and non-cognitive skills. For the $25^{\text {th }}, 50^{\text {th }}$ and $75^{\text {th }}$ percentiles of cognitive (non-cognitive) skills, I compute the probability of applying to an apprentice program, while fixing non-cognitive (cognitive) skills at their mean values. I also fix standardized income at the mean level and education of both parents at the secondary level. The general expectation is that for two pupils with the same background characteristics, apprenticeship application probability should be lower for pupils coming from a district with high excess supply as there is probably lower risk associated with admissions to vocational schools in such district.

Predicted probabilities of apprenticeship choice are displayed in Figures 6.7a-b. It is apparent that increased excess supply of apprenticeships generally results in a decrease in the predicted probability of applying for both females and males. As it is explained above, higher excess supply of apprenticeships should be associated with lower riskiness of admission to vocational school. Hence the decreasing pattern in the probability of applying to apprenticeships is an intuitive outcome, confirming that a greater supply of apprenticeships, likely associated with more options in the case of 
failing vocational school admission process, encourages pupils to apply for vocational schools. The outcome for males contradicts the result obtained by the estimation without interaction effects. This suggests that their inclusion is indeed very important. A sharper decrease observed for females and overall higher apprenticeship-application probabilities of males suggest that there are also other factors affecting the decision process of males and females differently. This is confirmed also by another result. As the measure of excess supply decreases (admission process risk goes up), the role of non-cognitive skills becomes more important for females, but the opposite is true for males. It is possible that a variety of apprentice programs that are possibly associated with their high excess supply in a district is sufficient incentive for boys to apply there. On the other hand, society may also consider apprenticeships to be more suitable for boys than for girls. The latter claim is supported by the overall higher probabilities of males applying for apprenticeship programs.

\section{DIRECT VS. INDIRECT EFFECTS OF PARENTAL BACKGROUND}

So far in standard probit analysis, I assumed that the measures of cognitive and non-cognitive skills are perfect proxies for true abilities. However, in the case that these measures are imprecise, estimation results are biased, generally for all the parameters in the equations. A standard approach to errors in variables is to use instrumental variables. An instrument has to be found that is correlated with a true, imprecisely measured factor and at the same time is uncorrelated with errors in measurement. Having such instruments implies consistent estimation. However, within the framework in this paper it is difficult to find adequate instruments, especially for non-cognitive skills. Moreover, the technique of instruments does not work in other than simple linear specifications. Therefore, I use a structural equation model approach with latent variables. ${ }^{12}$

Latent variables are variables that are not measurable but that are related to measurable factors (see Kmenta 1971, for a broader introduction). In this case, it is likely that precise measures of one's cognitive and non-cognitive skills are not existent, even though the outcomes of cognitive, psychological or intelligence tests do provide

\footnotetext{
${ }^{12}$ The model is originally known as LISREL (Linear Structural Relations) and can be thought of as a higher level of a MIMIC model (multiple-indicator multiple-cause). See Jöreskog (1973) and Jöreskog, Goldberger (1975).
} 
some information about the level of underlying skills. Because I have data on four types of cognitive tests available and data on two psychological scales, I can construct a structural model that relates latent skills to their respective measures. The model also contains an equation that describes the choice of secondary school as a function of these latent skills and background variables. Additionally, a structural model also allows for latent variables to be determined by other (measurable) factors including stochastic disturbance. As the determining factors I include dummies characterizing education of the parents. Hence, this framework allows for distinguishing between the direct effect of parental background (included in the equation for school choice) and the effect mediated through the level of skills.

I use a structural model representation, similar to one specified by Rabe-Hesketh, Skrondal and Pickles (2003). I specify an outcome model - a functional form for explaining the probability of applying to academic programs/apprenticeships. This model contains background characteristics, a variable measuring excess demand/supply of academic programs/apprenticeships and the two latent factors (for cognitive and noncognitive skills) as explanatory variables. Further, I specify a measurement model: a functional form explaining the levels of the latent skills measures. Finally, the true covariate model to explain the level of latent skills is added to the outcome model and the measurement model to form a structural specification.

\subsection{Model specification}

\section{Outcome model}

$$
\operatorname{Pr}(\boldsymbol{G}=1)=\Phi\left(\boldsymbol{X} \beta+\alpha \mathbf{E} \boldsymbol{D}^{\boldsymbol{D}}+\beta^{C} \boldsymbol{f}^{C}+\beta^{N} \boldsymbol{f}^{N}\right)
$$

The outcome model is specified to reflect the relationship between the outcome variable (whether one applies to a academic high school or not), the true latent cognitive and non-cognitive skills, $\boldsymbol{f}^{C}, \boldsymbol{f}^{N}$, and other background characteristics: individualspecific, $\boldsymbol{X}$, and district-specific excess demand for academic high schools (excess supply of apprenticeships): $\boldsymbol{E} \boldsymbol{D}^{\boldsymbol{D}}$ in district $\boldsymbol{D}$. 


\section{Measurement model}

I have 4 measures of cognitive skills obtained from PISA tests $\left(\boldsymbol{M}_{j}^{C}\right.$, measuring skills in mathematics, problem solving, reading literacy and science) and 2 measures of non-cognitive skills obtained from the supplementary pupil questionnaire $\left(\boldsymbol{M}_{\boldsymbol{k}}^{N}\right.$, measuring levels of self-esteem and self-control). In a measurement model, I assume that measures of cognitive skills are a function of latent cognitive skills and that measures of non-cognitive abilities are a function of latent non-cognitive abilities.

$$
\begin{gathered}
\boldsymbol{M}_{j}^{C}=\delta_{j}^{C}+\lambda_{j}^{C} f^{C}+\varepsilon_{j}^{C} \quad j=1,2,3,4 \\
M_{k}^{N}=\delta_{k}^{N}+\lambda_{j}^{N} f^{N}+\varepsilon_{k}^{N} \quad k=1,2
\end{gathered}
$$

The scales of the measurements are given by $\lambda$ and the mean deviation by $\delta$. A normalization of the mean and the scale of one measure of each skill to 0 and 1 respectively allows for identification. The errors associated with the measures of both skills are assumed to be normal and independent of true cognitive/non-cognitive skills.

\section{True covariate model}

The latent variables are assumed to be a function of a subset of all observed covariates, in this case a function of the education of the parents $\left(\boldsymbol{X}^{\mathrm{C}}=\boldsymbol{X}^{\mathrm{N}}\right)$.

$$
\begin{gathered}
\boldsymbol{f}^{C}=\gamma^{C} \boldsymbol{X}^{C}+\xi^{C} \\
\boldsymbol{f}^{N}=\gamma^{N} \boldsymbol{X}^{\prime N}+\xi^{N}
\end{gathered}
$$

The errors are again assumed to be normal, with zero mean and constant variance. For identification purposes, it is assumed that cognitive and non-cognitive skills are independent. The same assumption is made by Cunha et al. (2005) and is supported by correlations between the measures of cognitive and non-cognitive skills (see Table 7.1). 
I estimate the specified model by the maximum likelihood method, using a program gllamm $^{13}$ incorporated in STATA. This software adopts adaptive quadrature to evaluate maximum likelihood. Reported results are from the estimation in which I assume normality of underlined skills given the observed covariates. Because gllamm allows for relaxing this normality assumption using a non-parametric maximum likelihood procedure, I also perform such estimations. However, the results are very similar, therefore I do not report them. A drawback of the structural model is that the requirements for its identification do not allow for estimating interaction effects. Trying to resolve the problem by grouping observations to three groups according to ordered excess demand/excess supply and estimating the effect of background and skills within these groups does not lead to explainable results with magnitude and significance of the effects not following any pattern. Finer grouping cannot be done because of the small number of observations. The following results are hence based on the specification without interaction effects.

\subsection{Results}

Table 7.2 summarizes the coefficients and standard errors for the structural model for academic high school application. For comparison, also the results from the previous probit analysis without interaction terms are displayed. For boys, the significance as well as the signs of the effects in the main equation are the same for the structural model and probit model. The magnitudes of the effects, however, differ. The coefficients on tertiary education of both parents are smaller while the coefficient on cognitive skills is much greater than the coefficient from probit. This reflects the assumption embedded in the latent cognitive skill equation that cognitive skills are formed according to the background provided by the parents. The equation for latent cognitive skills indeed confirms that the level of these skills depends on the education of the parents, with a positive impact of a secondary degree and even larger positive impact of a tertiary degree attained by the parents. Non-cognitive skills of boys are found to be positively affected by their father's education but not by the education of

\footnotetext{
${ }^{13}$ Abbreviation gllamm stands for generalized linear latent and mixed models. The program combines features of generalized linear mixed models and structural equation modeling. The program can be downloaded at http://www.gllamm.org. For related literature, see e.g. of Rabe-Hesketh, Skrondal and Pickles (2002).
} 
their mother. They are, however, not found to predict the choice to apply to academic high school. In summary, sons of highly educated parents are more likely to apply to academic high schools, and the effect is not only direct but also indirect due to affecting both cognitive and non-cognitive skills of boys.

For girls, the education of their mother, unlike their father's education, seems to be a significant (direct and indirect) predictor of application choice. Girls' father's education has a positive impact on the level of cognitive skills, and a smaller significant impact of the father's secondary education on application probability is found. For girls, both cognitive and non-cognitive abilities predict the choice of academic high school. Again, the magnitudes differ- they are larger than the ones found using the probit analysis.

The effect of family income is positive and significant for boys with almost the same magnitude as in the probit model, while the effect for girls is insignificant. Insignificance is found, again, for excess demand for places at academic high schools. These unchanged outcomes on family income and excess demand obtained by a more complex, structural model suggest that cognitive and non-cognitive skills are quite good proxies for true levels of these skills.

Overall, the findings suggest that the differences in estimated coefficients from the probit and structural model are caused by not accounting for the effect of background variables on the formation of skills in the probit model. Once specifying the model for skills formation (as a function of education of parents), the coefficient on parental education (direct effect) becomes smaller (or insignificant) and the magnitude of the effect of skills gets larger. Interestingly, it seems that education of both parents is crucial for forming cognitive abilities. Non-cognitive skills of boys depend on the education of their fathers, while the level of these skills in the case of girls is affected by the education of their mothers. I return to these interesting findings in the concluding section.

Table 7.3 displays the coefficients and standard errors for the structural model for apprenticeship application along with the results from the probit model. The results for boys in the table are consistent with the results for the choice of academic high school- importance of parental education is lower in the structural model than in the standard probit. The opposite holds for both types of skills. The results for girls are 
similar. Concerning skills formation, again while cognitive skills are significantly determined by education of both parents, non-cognitive skills of girls are formed due to the mother's education, those of males are significantly affected by father's education.

\section{CONCLUSION}

Non-cognitive skills may have a significant impact on decisions. For instance, preference for today's income as opposed to income received after five years of additional schooling may induce individuals not to opt for higher education. Similarly, a low level of self-esteem would discourage a person from pursuing actions with a high but risky return (such as the choice of highly demanded schools). In this paper I deal with the determinants of application choices to secondary schools in the Czech Republic. Since admission to better schools is conditional on passing the admission process and failing may lead to ending up at an undesirable school, I explore the role of noncognitive abilities in the application decision, in addition to standard determinants: parental education, income and cognitive skills. Generally, the results show that the probabilities of applying to academic high schools and apprenticeships are affected predominantly by the level of cognitive skills and parents' education. The impact of family income is much less significant. The impact of non-cognitive skills is not as large as the effect of cognitive abilities; it is totally insignificant with respect to male decisions between academic high school and vocational school. Most importantly, however, the importance of non-cognitive skills changes with the district-specific risk of ending up at an undesired school in the intuitively predictable ways for females, but not for males.

The analysis in this paper generally shows the important differences between boys and girls. First, the probability of applying to an academic high school for girls is much higher than for boys, given the secondary education of parents, average income and the same excess demand for academic high schools. On the other hand, the probability of applying to an apprentice program is much higher for a boy than for a similarly skilled girl with the same background. These outcomes may reflect some societal customs and norms. As stated by Myslivecek and Knot (2004), parents consider academic high school to be the most appropriate type of secondary school for girls. 
However, even if we accept that there is some fixed probability difference between boys and girls, there are other striking outcomes that are of interest.

As far as the female choice between academic high school and vocational school is considered, the districts with higher excess demand for academic high schools are characterized by the strengthened importance of non-cognitive abilities and weakened importance of cognitive skills for probability to apply to academic program. This is in accordance with the hypothesis that uncertainty associated with high excess demand provides more space for non-cognitive skills (in this case possibly thought of as confidence) to influence the application decision. For males, however, the effect of noncognitive skills is not found and the influence of cognitive abilities increases as excess demand is higher. Moreover, the academic high school application probability of males with high cognitive abilities increases as the risk associated with the application process increases. I offer an explanation for these outcomes that relates to the proposition that vocational schools are generally a good alternative to academic high schools for males. In the case that the districts with high values of excess demand for academic high schools also provide higher quality education in academic high schools, and the districts with low values of excess demand are characterized by lower quality of academic high schools, we would observe higher frequency of males applying to academic high schools in "higher-quality" districts. One way how to evaluate the quality of the secondary school is by the percentage chances of entering university later on. Then, males aspiring for tertiary education, not discouraged by the technical orientation of many vocational schools, apply for them in districts with subsequent chances to get into a university comparable to those of academic high school graduates. If the fromvocational-school-to-university chances are lower in a district, we should observe boys applying to academic high schools more frequently. There is definitely space for further research to elaborate on this explanation.

With respect to the estimation of the probability of applying for an apprenticeship, the decreasing pattern of predicted probability with increasing excess supply of apprentice programs is found for both males and females. This is in accordance with the intuition that higher supply of apprenticeships is likely associated with more options in the case of failing vocational school admission process, and this encourages pupils to apply for vocational schools instead of apprenticeships. However, 
there are also some important gender differences. As the measure of excess supply decreases (admission process risk goes up) the role of non-cognitive skills becomes more important for females, but the opposite is true for males. It is possible that a variety of apprentice programs that are likely to be associated with their high excess supply in a district is sufficient incentive for males to apply there. Or, it is possible that the districts with high excess supply of apprenticeships are also characterized by the labor market biased towards male jobs, capable of absorbing the variety of apprenticeship programs. Again, similarly as in the case of academic high schools, further research should address the validity of these explanations in order to resolve the reasons behind the gender differences in application decisions.

It is possible to check the subset of observations that include information on the success of a pupil in the first round and his/her final outcome in the form of the type of the school he/she finally got into. The outcomes suggest that a large majority of pupils in the sub-sample manage to get to the school type desired in the first round (see Table 8.1). In other words, pupils very accurately assessed their chances for the type they applied to, even though this conjecture is based on a non-representative sample. ${ }^{14}$ This does not prove, of course, that pupils apply to the school actually preferred.

Aside from strategic reasons of boys (university admission chances, district labor market features), the gender differences observed so far may be also associated with outcomes obtained by estimating the structural model of choice, in which I model the formation of skills as the function of education of the parents. While cognitive skills are found to be significantly determined by education of both parents, non-cognitive skills of females are formed due to education of the mother and those of males are significantly affected by the father's education. This is confirmed also by regressing standardized averages of measures of cognitive and non-cognitive skills on educational dummies (see Table 9.1). It is possible then that the "quality" of skills differs between men and women. Alternatively, the psychological scales in PISA amendment may measure them differently for males and females. However, it is beyond the capabilities

\footnotetext{
${ }^{14}$ This sub-sample is not representative of the population since there are $24 \%, 56 \%, 20 \%$ pupils in the sub-sample applying in the first round to academic high schools, vocational schools and apprenticeships, respectively, with very similar percentages getting into the given type. On a national level, however, in $2003,15 \%, 53 \%$, and $32 \%$ applied to academic high schools, vocational schools and apprenticeships, respectively, in the first round, finally ending in the proportions $12 \%, 44 \%$ and $44 \%$ at academic high schools, vocational programs and apprenticeships, respectively.
} 
of economic literature to resolve the extent to which observed gender differences in formation of non-cognitive skills relate to differences in application behavior.

The outcomes of this paper also indicate that there may be a significant residual role for the perceptions about the suitability of specific school types for boys and girls in the Czech Republic leading to discouraging a lot of boys from pursuing academic or vocational school education, even though their skills are comparable to those of girls pursuing academic type of education or vocational schools. Hence the policy advocating equal chances for education should not only concentrate on children from disadvantaged families but also on encouraging highly skilled boys to apply to schools of better quality. Of course, first, it is necessary to investigate whether the behavior of boys is not to some extent strategic, i.e., whether they do apply to vocational school because of high chances of being admitted to university, or whether they do apply for apprenticeships because of the specific favorable characteristics of labor market. 


\section{REFERENCES}

Burdová, Pavla, Petr Matějů, and Ivana Procházková. 2003. "Skryté stránky prijímacího

řízení na vysoké školy," in Vyšší vzdelání jen pro elitu? Rozsah a zdroje nerovností v přístupu $\mathrm{k}$ vyššímu vzdělání v České republice, Institut pro sociální a ekonomické analýzy, pp. 33-64.

Cameron, Stephen, and James J. Heckman. 1999. "Can Tuition Policy Combat Rising Wage Inequality?" In Financing College Tuition: Government Policies and Educational Priorities, ed. Martin Kosters. Washington, D.C.: American Enterprise Institute Press.

Cunha, Flavio, James J. Heckman, Lance Lochner, and Dimitriy V. Masterov. 2005. "Interpreting the Evidence on Life Cycle Formation.” IZA Working Paper 1675.

Campos, Nauro F., and Dean Jolliffe. 2003. "After, Before and During: Returns to Education in Hungary (1986-1998)." Economic Systems, 27: 377-90.

Dustmann, Christian. 2004. "Parental Background, Secondary School Track Choice, and Wages." Oxford Economic Papers, 56: 209-30.

Filer, Randall K., and Daniel Munich. 2002. "Responses of Private and Public Schools to Voucher Funding." Paper presented at American Economic Association (AEA) Annual Meeting, January 2003, Washington D.C.

Heckman, James J., Jora Stixrud, and Sergio Urzua. 2006. "The Effects of Cognitive and Noncognitive Abilities on Labor Market Outcomes and Social Behavior." Journal of Labor Economics, 24(3): 411-82.

Jöreskog, Karl G. 1973. "A general method for estimating a linear structural equation system.” In Structural Equation Models in the Social Sciences, ed. Arthur S. Goldberger, Otis D. Duncan, 55-112. New York: Seminar Press.

Jöreskog, Karl G., and Arthur S. Goldberger. 1975. "Estimation of a model with multiple indicators and multiple causes of a single latent variable." Journal of the American Statistical Association, 70: 631-39.

Kmenta, Jan. 1971. Elements of Econometrics. New York: Macmillan.

Munich, Daniel, and Ondrej Knot. 2004. "Estimating the Impact of School Quality, Selection, and Supply on Student's Achievements: Evidence from The Czech Nationwide Testing of Youth.” Paper presented at CSE congress, 2004.

Munich, Daniel, and Ondrej Knot. 2006a. "Efficiency and Equity Implications of Selective School Admission Procedures: The Case of the Czech Republic." mimeo. 
Munich, Daniel, and Ondrej Knot. 2006b. "An empirical paper on the choice of secondary education in the Czech Republic." mimeo.

Munich, Daniel, and Jan Myslivecek. 2006. "Prechod zaku na stredni skoly: diskrepance mezi nabidkou a poptavkou a jeji dusledky [Pupils' Transition to Secondary Schools: Discrepancy between Demand and Supply and its Consequences]" In (Ne)rovné šance na vzdělání, pp. 247-281, ed. Petr Mateju and Jana Strakova. Praha: Academia.

Munich, Daniel, Jan Svejnar, and Katherine Terrell. 2005. "Returns to Human Capital under the Communist Wage Grid and during the Transition to a Market Economy."

Review of Economics and Statistics 87: 100-123.

Norton, Edward C., Hua Wang, and Chunrong Ai. 2004. "Computing Interaction Effects and Standard Errors in Logit and Probit Models." The Stata Journal, 4(2): 15467.

Rabe-Hesketh, Sofia, Anders Skrondal, and Andrew Pickles. 2003. "Maximum Likelihood Estimation of Generalized Linear Models with Covariate Measurement Error." The Stata Journal, 3(4): 385-410.

Rabe-Hesketh, Sofia, Anders Skrondal, and Andrew Pickles. 2002. "Reliable Estimation of Generalized Linear Mixed Models Using Adaptive Quadrature." The Stata Journal 2: 1-21.

Rosenberg, Morris. 1965. Society and the Adolescent Self-Image. Princeton, NJ: Princeton University Press

Rotter, Julian B. 1966. Generalized Expectancies for Internal Versus External Control of Reinforcement. Washington DC: American Psychological Association. 


\section{APPENDIX 1 - TABLES}

\section{Table 5.1}

Descriptive statistics - individually specific variables

\begin{tabular}{|c|c|c|c|c|c|c|c|c|c|c|}
\hline \multirow[b]{2}{*}{ Variable } & \multicolumn{5}{|c|}{ MALES } & \multicolumn{5}{|c|}{ FEMALES } \\
\hline & Obs & Mean & Std. Dev. & Min & Max & Obs & Mean & Std. Dev. & Min & Max \\
\hline Secondary education of mother (dummy) & 1162 & 0.46 & 0.50 & 0 & 1 & 1241 & 0.41 & 0.49 & $\mathbf{0}$ & 1 \\
\hline Tertiary education of mother (dummy) & 1162 & 0.21 & 0.40 & 0 & 1 & 1241 & 0.17 & 0.38 & 0 & 1 \\
\hline Secondary education of father (dummy) & 1162 & 0.33 & 0.47 & 0 & 1 & 1241 & 0.29 & 0.45 & 0 & 1 \\
\hline Tertiary education of father (dummy) & 1162 & 0.18 & 0.38 & 0 & 1 & 1241 & 0.17 & 0.38 & 0 & 1 \\
\hline Standardized income per $\mathrm{HH}$ member (CZK) & 1162 & 7982 & 3795 & 2000 & 32000 & 1241 & 7754 & 3755 & 2000 & 32000 \\
\hline 1st application choice: grammar school (dummy) & 1162 & 0.15 & 0.36 & 0 & 1 & 1241 & 0.27 & 0.44 & 0 & 1 \\
\hline 1st application choice: vocational school (dummy) & 1162 & 0.51 & 0.50 & 0 & 1 & 1241 & 0.56 & 0.50 & 0 & 1 \\
\hline 1st application choice: apprenticeship (dummy) & 1162 & 0.34 & 0.47 & 0 & 1 & 1241 & 0.17 & 0.38 & 0 & 1 \\
\hline Standardized score on cognitive skills & 1162 & 0.22 & 1.04 & -3.58 & 3.06 & 1241 & 0.12 & 0.91 & -3.33 & 3.48 \\
\hline Score on PISA test: Mathematics & 1162 & 525.39 & 87.45 & 223.28 & 816.34 & 1241 & 506.54 & 80.78 & 170.11 & 816.34 \\
\hline Score on PISA test: Reading literacy & 614 & 483.04 & 93.13 & 143.67 & 740.87 & 662 & 505.95 & 78.48 & 236.65 & 740.87 \\
\hline Score on PISA test: Problem solving & 600 & 523.69 & 87.08 & 215.57 & 776.49 & 679 & 512.63 & 76.47 & 237.69 & 745.42 \\
\hline Score on PISA test: Science & 656 & 527.58 & 95.85 & 197.04 & 818.40 & 656 & 517.75 & 87.45 & 200.19 & 841.53 \\
\hline Standardized score on non- cognitive skills & 1162 & 0.16 & 1.03 & -4.57 & 3.26 & 1241 & -0.02 & 0.97 & -3.70 & 3.26 \\
\hline Score on Rosenberg scale: self-esteem & 1150 & 12.01 & 2.53 & 1 & 18 & 1234 & 11.46 & 2.40 & 1 & 18 \\
\hline Score on Rotter scale: self control & 1146 & 12.74 & 2.72 & 2 & 21 & 1234 & 12.45 & 2.60 & 3 & 21 \\
\hline
\end{tabular}

Note: Number of observations for all choices of secondary school is constrained by having data on parental education. When estimating probability of applying to academic high school (apprenticeship), number of observations is 768 and 1027 (982 and 911) for males and females, respectively).

Table 5.2

Cognitive and non-cognitive skills: means and standard deviations according to gender and choice of secondary school

\begin{tabular}{|c|c|c|c|c|c|c|c|c|}
\hline \multirow[b]{3}{*}{ 1st choice of a pupil } & \multicolumn{8}{|c|}{ Means and standard deviations of standardized averages of cognitive and non-cognitive skills } \\
\hline & \multicolumn{2}{|c|}{ Cognitive skills } & \multicolumn{2}{|c|}{ Non-cognitive skills } & \multicolumn{2}{|c|}{ Cognitive skills } & \multicolumn{2}{|c|}{ Non-cognitive skills } \\
\hline & Mean & Std. Dev. & Mean & Std. Dev. & Mean & Std. Dev. & Mean & Std. Dev. \\
\hline Apprenticeship & -0.55 & 0.86 & -0.16 & 1.01 & -0.76 & 0.76 & -0.54 & 0.88 \\
\hline Vocational school & 0.49 & 0.84 & 0.29 & 0.97 & 0.06 & 0.77 & -0.03 & 0.96 \\
\hline Academic high school & 1.02 & 0.90 & 0.41 & 1.05 & 0.80 & 0.72 & 0.28 & 0.95 \\
\hline Total & 0.20 & 1.04 & 0.15 & 1.02 & 0.10 & 0.91 & -0.04 & 0.98 \\
\hline
\end{tabular}

Table 5.3

Household income per capita - means and standard deviations according to gender and choice of secondary school, in Czech crowns

\begin{tabular}{|c|c|c|c|c|}
\hline \multirow[b]{3}{*}{ 1st choice of a pupil } & \multicolumn{4}{|c|}{$\begin{array}{l}\text { Means and standard deviations of per-capita household } \\
\text { income }\end{array}$} \\
\hline & \multicolumn{2}{|c|}{ MALES } & \multicolumn{2}{|c|}{ FEMALES } \\
\hline & Mean & Std. Dev. & Mean & Std. Dev. \\
\hline Apprenticeship & 6566 & 2672 & 6328 & 3138 \\
\hline Vocational school & 8098 & 3674 & 7412 & 3408 \\
\hline Academic high school & 10366 & 4737 & 9211 & 4464 \\
\hline Total & 7895 & 3758 & 7675 & 3791 \\
\hline
\end{tabular}


Table 5.4

Estimation of demand for academic high schools for elementary school graduates

\begin{tabular}{|l|c|}
\hline Dependent variable: Demand for academic high schools & $\begin{array}{c}\text { Regression } \\
\text { coefficients }\end{array}$ \\
\hline Share of population with tertiary degree & $\mathbf{0 . 6 2} * *$ \\
& $(0.24)$ \\
Presence of public university & $-\mathbf{0 . 0 3} * *$ \\
Share of places at 4-year academic high schools out of & $\mathbf{0 . 0 1 )}$ \\
all places at academic high schools & $\mathbf{0 . 2 0} * * *$ \\
Constant & $(0.03)$ \\
& -0.01 \\
Adjusted R2 & $(0.02)$ \\
N & 0.50 \\
$* * *$ significant at 1\% ** significant at 5\% * significant at $10 \%$ \\
\hline
\end{tabular}

Table 5.5

Estimation of demand for apprenticeships for elementary school graduates

\begin{tabular}{|l|c|}
\hline Dependent variable: Demand for apprenticeships & $\begin{array}{c}\text { Regression } \\
\text { coefficients }\end{array}$ \\
\hline Share of population with education without GCE & $\mathbf{0 . 9 9}{ }^{* \star}$ \\
Constant & $(0.25)$ \\
& $-\mathbf{0 . 2 3}$ \\
Adjusted R2 & $(0.16)$ \\
N & 0.18 \\
\hline
\end{tabular}

$* * *$ significant at $1 \% \quad * *$ significant at $5 \% *$ significant at $10 \%$

\section{Table 6.1}

Determinants of academic high school application choice Marginal effects from a probit model

\begin{tabular}{|c|c|c|c|c|c|c|}
\hline $\begin{array}{l}\text { Dependent variable: Dummy for a choice of } \\
\text { academic high school }\end{array}$ & \multicolumn{6}{|c|}{ Marginal probability of applying to academic high school } \\
\hline & $(1)$ & $(2)$ & $(3)$ & $(4)$ & $(5)$ & $(6)$ \\
\hline Secondary education of mother & $\begin{array}{r}0.03 \\
(0.05)\end{array}$ & $\begin{array}{r}0.04 \\
(0.05)\end{array}$ & & $\begin{array}{l}\mathbf{0 . 1 2} \text { *** } \\
(0.04)\end{array}$ & 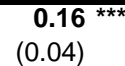 & \\
\hline Tertiary education of mother & $\begin{array}{l}0.13 \\
(0.06)\end{array}$ & $\begin{array}{l}0.17 \\
(0.06)\end{array}$ & & $\begin{array}{l}0.27 \\
(0.06)\end{array}$ & $\begin{array}{l}0.34 \\
(0.06)\end{array}$ & \\
\hline Secondary education of father & $\begin{array}{l}-0.04 \\
(0.04)\end{array}$ & $\begin{array}{l}-0.01 \\
(0.04)\end{array}$ & & $\begin{array}{l}0.09 \\
(0.04)\end{array}$ & $0^{0.11}{ }^{* * *}$ & \\
\hline Tertiary education of father & $\begin{array}{l}0.17 \\
(0.06)\end{array}$ & $\begin{array}{l}0.20 \\
(0.06)\end{array}$ & & $\begin{array}{l}0.11 \\
(0.06)\end{array}$ & $\begin{array}{l}0.18 \text { *** } \\
(0.06)\end{array}$ & \\
\hline Standardized income per $\mathrm{HH}$ member & $\begin{array}{l}0.04 \text { ** } \\
(0.02)\end{array}$ & $\begin{array}{l}\mathbf{0 . 0 4} \\
(0.02)\end{array}$ & $\begin{array}{l}0.08 \text { *** } \\
(0.02)\end{array}$ & $\begin{array}{r}0.02 \\
(0.02)\end{array}$ & $\begin{array}{r}0.03 \\
(0.02)\end{array}$ & $\begin{array}{l}\mathbf{0 . 0 6} \\
(0.02)\end{array}$ \\
\hline Excess demand for academic high schools & $\begin{array}{r}-0.94 \\
(0.80)\end{array}$ & $\begin{array}{r}-0.68 \\
(0.75)\end{array}$ & $\begin{array}{l}-1.03 \\
(0.80)\end{array}$ & $\begin{array}{r}-0.11 \\
(1.07)\end{array}$ & $\begin{array}{r}0.59 \\
(0.97)\end{array}$ & $\begin{array}{r}-0.36 \\
(0.92)\end{array}$ \\
\hline Standardized score on cognitive skills & $\begin{array}{l}0.09 \\
(0.03)\end{array}$ & & $\begin{array}{l}0.11 \\
(0.03)\end{array}$ & $\begin{array}{l}0.22 \\
(0.02)\end{array}$ & & $\begin{array}{l}0.25 * * * \\
(0.02)\end{array}$ \\
\hline Standardized score on noncognitive skills & $\begin{array}{r}0.00 \\
(0.01)\end{array}$ & & $\begin{array}{r}0.01 \\
(0.01)\end{array}$ & $\begin{array}{l}0.03 \\
(0.02)\end{array}$ & & $\begin{array}{l}0.04 \\
(0.02)\end{array}$ \\
\hline Pseudo R2 & 0.16 & 0.12 & 0.10 & 0.21 & 0.11 & 0.17 \\
\hline $\mathrm{N}$ & 768 & 768 & 768 & 1027 & 1027 & 1027 \\
\hline
\end{tabular}

$* * *$ significant at $1 \% \quad * *$ significant at $5 \% *$ significant at $10 \%$ 


\section{Table 6.2}

Determinants of academic high school application choice

Coefficients from a model with interactions of excess demand for academic high schools with background characteristics and skills

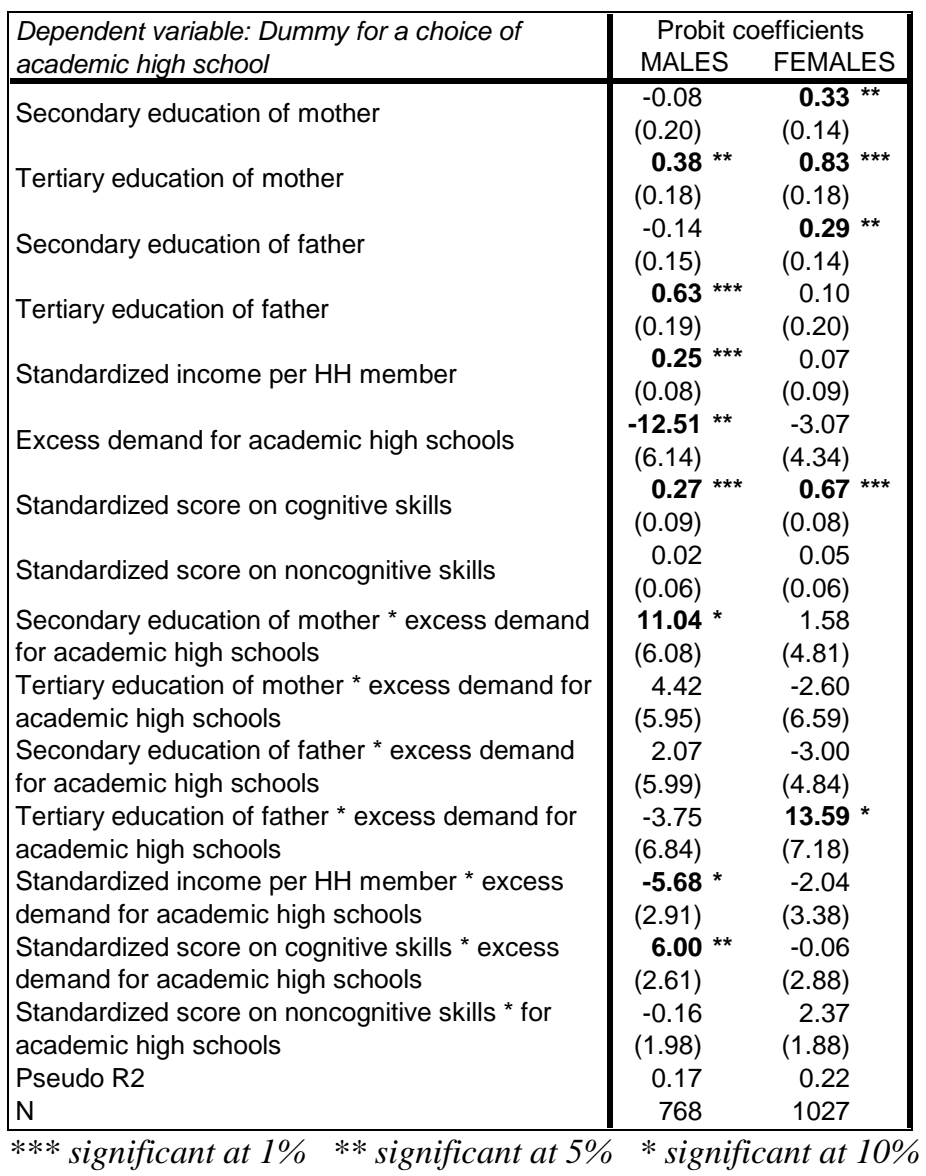




\section{Table 6.3}

Determinants of apprenticeship application choice Marginal effects from a probit model

\begin{tabular}{|c|c|c|}
\hline \multirow[t]{2}{*}{$\begin{array}{l}\text { Dependent variable: Dummy for a choice of } \\
\text { apprenticeship }\end{array}$} & \multicolumn{2}{|c|}{$\begin{array}{l}\text { Marginal probability of } \\
\text { applying to } \\
\text { apprenticeship }\end{array}$} \\
\hline & MALES & FEMALES \\
\hline Secondary education of mother & $\begin{array}{l}-0.13 * \star * \\
(0.05)\end{array}$ & $\begin{array}{l}-0.14 * * * \\
(0.03)\end{array}$ \\
\hline Tertiary education of mother & $\begin{array}{l}-0.12 * \\
(0.06)\end{array}$ & $\begin{array}{l}-0.18 \text { *** } \\
(0.02)\end{array}$ \\
\hline Secondary education of father & $\begin{array}{l}-0.15 * * * \\
(0.05)\end{array}$ & $\begin{array}{r}-0.02 \\
(0.03)\end{array}$ \\
\hline Tertiary education of father & $\begin{array}{l}-0.26 * * * \\
(0.05)\end{array}$ & $\begin{array}{c}0.11 \\
(0.08)\end{array}$ \\
\hline Standardized income per $\mathrm{HH}$ member & $\begin{array}{l}-0.08 * * * \\
(0.03)\end{array}$ & $\begin{array}{l}-0.05 * * \\
(0.02)\end{array}$ \\
\hline Excess supply of apprenticeships & $\begin{array}{l}1.06 * * * \\
(0.41)\end{array}$ & $\begin{array}{r}-0.28 \\
(0.26)\end{array}$ \\
\hline Standardized score on cognitive skills & $\begin{array}{l}-0.27 * * * \\
(0.05)\end{array}$ & $\begin{array}{l}-0.18 * * * \\
(0.02)\end{array}$ \\
\hline Standardized score on noncognitive skills & $\begin{array}{l}-0.05 * * \\
(0.02)\end{array}$ & $\begin{array}{l}-0.05 * * * \\
(0.02)\end{array}$ \\
\hline Pseudo R2 & 0.30 & 0.28 \\
\hline $\mathrm{N}$ & 982 & 911 \\
\hline
\end{tabular}




\section{Table 6.4}

Determinants of apprenticeship application choice

Coefficients from a model with interactions of excess supply of apprenticeships with background characteristics and skills

\begin{tabular}{|c|c|c|}
\hline \multirow{2}{*}{$\begin{array}{l}\text { Dependent variable: Dummy for a choice of } \\
\text { apprenticeship }\end{array}$} & \multicolumn{2}{|c|}{ Probit coefficients } \\
\hline & MALES & FEMALES \\
\hline Secondary education of mother & $\begin{array}{l}-0.44 * \star \star \\
(0.13)\end{array}$ & $\begin{array}{l}-0.60^{* * *} \\
(0.16)\end{array}$ \\
\hline Tertiary education of mother & $\begin{array}{l}-0.35 * \\
(0.18)\end{array}$ & $\begin{array}{l}-1.50 * * * \\
(0.35)\end{array}$ \\
\hline Secondary education of father & $\begin{array}{l}-0.42 * * * \\
(0.13)\end{array}$ & $\begin{array}{l}-0.28 * \\
(0.14)\end{array}$ \\
\hline Tertiary education of father & $\begin{array}{l}-0.92 * * * \\
(0.22)\end{array}$ & $\begin{array}{r}0.33 \\
(0.26)\end{array}$ \\
\hline Standardized income per $\mathrm{HH}$ member & $\begin{array}{l}-0.23 \\
(0.08)\end{array}$ & $\begin{array}{l}-0.13 \\
(0.09)\end{array}$ \\
\hline Excess supply of apprenticeships & $\begin{array}{l}4.53 \\
(1.79)\end{array}$ & $\begin{array}{r}0.15 \\
(1.88)\end{array}$ \\
\hline Standardized score on cognitive skills & $\begin{array}{l}-0.74 \\
(0.09)\end{array}$ & $\begin{array}{l}-0.82 * * * \\
(0.10)\end{array}$ \\
\hline Standardized score on no & $\begin{array}{l}-0.12 * * \\
(0.05)\end{array}$ & $\begin{array}{l}-0.20 * * * \\
(0.07)\end{array}$ \\
\hline er * excess & $\begin{array}{l}-4.75 * * \\
(1.95)\end{array}$ & $\begin{array}{r}2.28 \\
(2.20)\end{array}$ \\
\hline $\begin{array}{l}\text { Tertiary education of mother * excess supply } \\
\text { of apprenticeships }\end{array}$ & $\begin{array}{r}1.80 \\
(2.89)\end{array}$ & 1. \\
\hline $\begin{array}{l}\text { Secondary education of father * excess } \\
\text { supply of apprenticeships }\end{array}$ & $\begin{array}{r}-0.34 \\
(2.52)\end{array}$ & $\begin{array}{l}-6.40 * * * \\
(2.19)\end{array}$ \\
\hline $\begin{array}{l}\text { Tertiary education of father * excess supply } \\
\text { of apprenticeships }\end{array}$ & $\begin{array}{r}5.54 \\
(4.74)\end{array}$ & $\begin{array}{r}-2.46 \\
(4.34)\end{array}$ \\
\hline $\begin{array}{l}\text { Standardized income per } \mathrm{HH} \text { member * } \\
\text { excess supply of apprenticeships }\end{array}$ & $\begin{array}{r}-0.88 \\
(1.40)\end{array}$ & $\begin{array}{r}2.35 \\
(1.50)\end{array}$ \\
\hline Standardized score on cognitive skills * & -1.25 & -1.35 \\
\hline exce & (1.99) & $(1.29)$ \\
\hline $\begin{array}{l}\text { Standardized score on noncognitive skills * } \\
\text { excess supply of apprenticeships }\end{array}$ & $\begin{array}{r}0.34 \\
(0.94)\end{array}$ & $\begin{array}{r}1.08 \\
(1.22)\end{array}$ \\
\hline Pseu & 0.31 & 0.29 \\
\hline $\mathrm{N}$ & 982 & 911 \\
\hline
\end{tabular}




\section{Table 7.1}

Correlations between measures of cognitive and non-cognitive skills for those participating in all cognitive tests and the two particular cognitive tests

\begin{tabular}{|c|c|c|c|c|c|c|}
\hline \multirow{2}{*}{\multicolumn{7}{|c|}{\begin{tabular}{|l|}
226 observations - Those participating in all \\
tests
\end{tabular}}} \\
\hline & & & & & & \\
\hline Mathematics & 1.00 & & & & & \\
\hline Reading literacy & 0.61 & 1.00 & & & & \\
\hline Problem solving & 0.69 & 0.64 & 1.00 & & & \\
\hline Science & 0.61 & 0.66 & 0.58 & 1.00 & & \\
\hline Self-esteem & 0.27 & 0.26 & 0.17 & 0.25 & 1.00 & \\
\hline Self control & 0.16 & 0.26 & 0.17 & 0.19 & 0.56 & 1.00 \\
\hline \multicolumn{7}{|l|}{$\begin{array}{l}1447 \text { observations - Those participating in } \\
\text { mathematics and reading literacy tests }\end{array}$} \\
\hline Mathematics & 1.00 & & & & & \\
\hline Reading literacy & 0.54 & 1.00 & & & & \\
\hline Self-esteem & 0.26 & 0.23 & & & 1.00 & \\
\hline Self control & 0.22 & 0.24 & & & 0.58 & 1.00 \\
\hline \multicolumn{7}{|l|}{$\begin{array}{l}1429 \text { observations - Those participating in } \\
\text { mathematics and problem solving tests }\end{array}$} \\
\hline Mathematics & 1.00 & & & & & \\
\hline Problem solving & 0.66 & & 1.00 & & & \\
\hline Self-esteem & 0.28 & & 0.20 & & 1.00 & \\
\hline Self control & 0.24 & & 0.20 & & 0.60 & 1.00 \\
\hline \multicolumn{7}{|l|}{$\begin{array}{l}1463 \text { observations - Those participating in } \\
\text { mathematics and science tests }\end{array}$} \\
\hline Mathematics & 1.00 & & & & & \\
\hline Science & 0.56 & & & 1.00 & & \\
\hline Self-esteem & 0.25 & & & 0.21 & 1.00 & \\
\hline Self control & 0.23 & & & 0.23 & 0.59 & 1.00 \\
\hline
\end{tabular}

Note: Participation in two specific cognitive tests does not exclude participation in other cognitive tests. All correlations are significant at the $1 \%$ level. 


\section{Table 7.2}

Determinants of academic high school application choice

Coefficients from a structural model with latent variables, comparison with probit

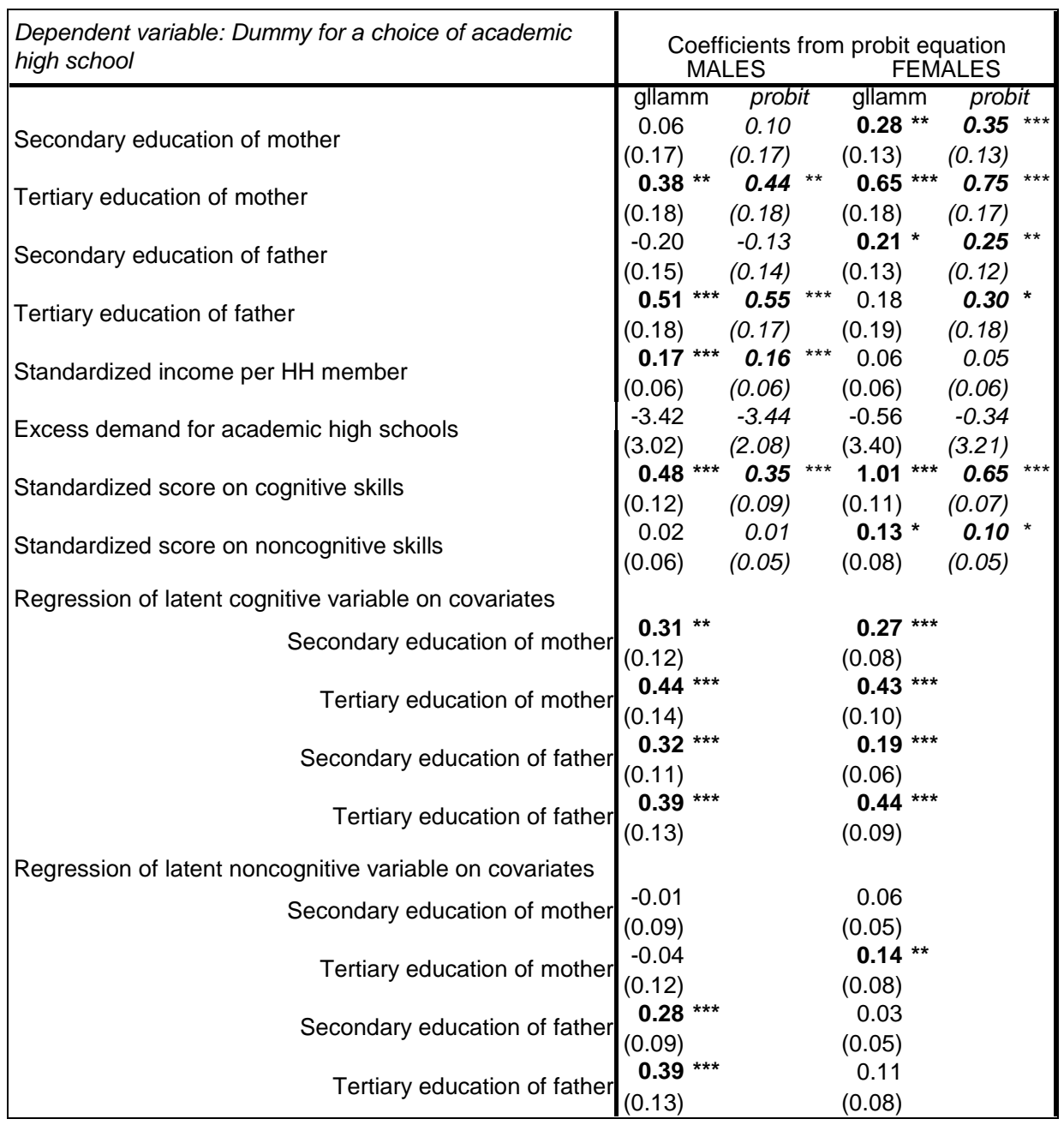

*** significant at $1 \% \quad * *$ significant at $5 \% \quad *$ significant at $10 \%$ 


\section{Table 7.3}

Determinants of apprenticeship application choice

Coefficients from a structural model with latent variables, comparison with probit

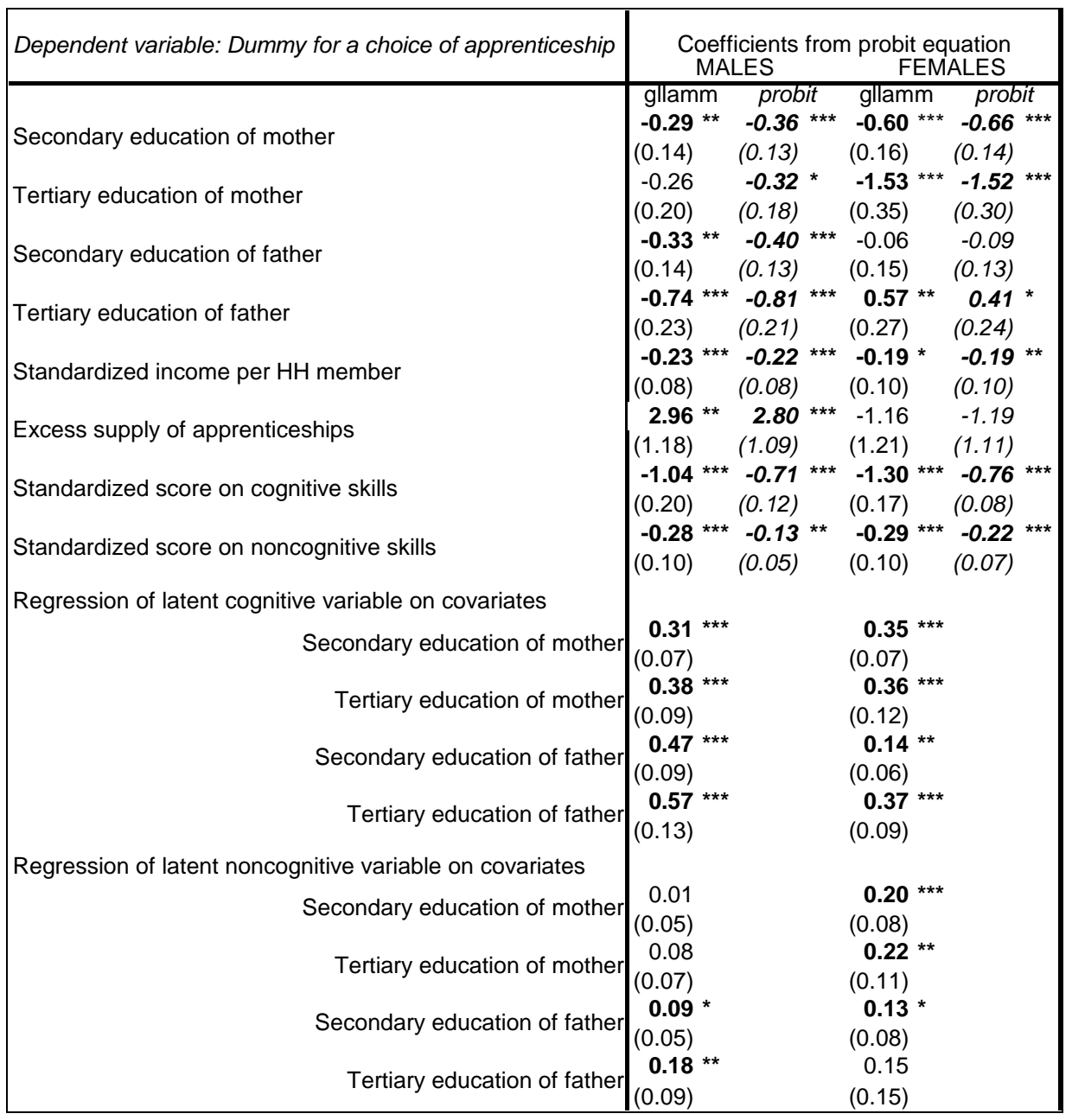

$* * *$ significant at $1 \% \quad * *$ significant at $5 \% *$ significant at $10 \%$ 


\section{Table 8.1}

Number of pupils who applied in the first round to the specific school types vs. number admitted to the specific school types: in total, in the second round, in the third round

\begin{tabular}{|c|c|c|c|}
\hline \multirow[b]{2}{*}{ Admitted to: } & \multicolumn{3}{|c|}{ Applied to in the first round: } \\
\hline & Apprenticeships & Vocational schools & Grammar schools \\
\hline & \multicolumn{3}{|c|}{ MALES - total } \\
\hline Apprenticeships & 177 & 9 & \\
\hline Vocational schools & 3 & 329 & 7 \\
\hline \multirow[t]{2}{*}{ Academic high schools } & & 2 & 111 \\
\hline & \multicolumn{3}{|c|}{ FEMALES - total } \\
\hline Apprenticeships & 77 & 14 & 1 \\
\hline Vocational schools & 1 & 372 & 12 \\
\hline \multirow[t]{2}{*}{ Academic high schools } & & 2 & 188 \\
\hline & \multicolumn{3}{|c|}{ Males admitted in the second round } \\
\hline Apprenticeships & 14 & 7 & \\
\hline Vocational schools & 2 & 24 & 7 \\
\hline \multirow[t]{2}{*}{ Academic high schools } & & 1 & 11 \\
\hline & \multicolumn{3}{|c|}{ Females admitted in the second round } \\
\hline Apprenticeships & 11 & 10 & \\
\hline Vocational schools & 1 & 47 & 12 \\
\hline \multirow[t]{2}{*}{ Academic high schools } & & 1 & 13 \\
\hline & \multicolumn{3}{|c|}{ Males admitted after the second round } \\
\hline Apprenticeships & 2 & 4 & 1 \\
\hline Vocational schools & & 10 & \\
\hline Academic high schools & & 1 & \\
\hline \multirow{4}{*}{$\begin{array}{l}\text { Apprenticeships } \\
\text { Vocational schools } \\
\text { Academic high schools }\end{array}$} & \multicolumn{3}{|c|}{ Females admitted after the second round } \\
\hline & 8 & 2 & \\
\hline & 1 & 6 & \\
\hline & & 1 & 1 \\
\hline
\end{tabular}

\section{Table 9.1}

Regression of standardized averages of (non-) cognitive skills measures on dummies for parental education

\begin{tabular}{|c|c|c|c|c|}
\hline & \multicolumn{4}{|c|}{ Coefficients from regressions by gender } \\
\hline & \multicolumn{2}{|c|}{$\begin{array}{l}\text { Dependent variable: } \\
\text { Standardized cognitive } \\
\text { skills }\end{array}$} & \multicolumn{2}{|c|}{$\begin{array}{l}\text { Dependent variable: } \\
\text { Standardized non- } \\
\text { cognitive skills }\end{array}$} \\
\hline \multirow{3}{*}{ Secondary education of mother } & MALES & FEMALES & MALES & FEMALES \\
\hline & $0.31 * * *$ & $0.45 * \star *$ & 0.06 & $0.22 * \star \star$ \\
\hline & $(0.07)$ & $(0.07)$ & $(0.08)$ & $(0.07)$ \\
\hline \multirow{2}{*}{ Tertiary education of mother } & $0.53 * * *$ & $0.68 * * *$ & 0.10 & $0.35 * * *$ \\
\hline & $(0.09)$ & $(0.09)$ & $(0.12)$ & $(0.11)$ \\
\hline Secondary education of father & $\begin{array}{l}0.49 \text { *** } \\
(0.09)\end{array}$ & $\begin{array}{l}0.23 \text { *** } \\
(0.06)\end{array}$ & $\begin{array}{l}0.23 \text { *** } \\
(0.08)\end{array}$ & $\begin{array}{c}\mathbf{0 . 1 1} \\
(0.06)\end{array}$ \\
\hline \multirow{2}{*}{ Tertiary education of father } & $0.66 * * *$ & $0.44 * * *$ & $0.46 * * *$ & 0.17 \\
\hline & $(0.12)$ & $(0.09)$ & $(0.12)$ & $(0.11)$ \\
\hline
\end{tabular}




\section{APPENDIX 2 - FIGURES}

\section{Figure 5.1}

Sample distribution of standardized average measure of cognitive and non-cognitive skills for males and females
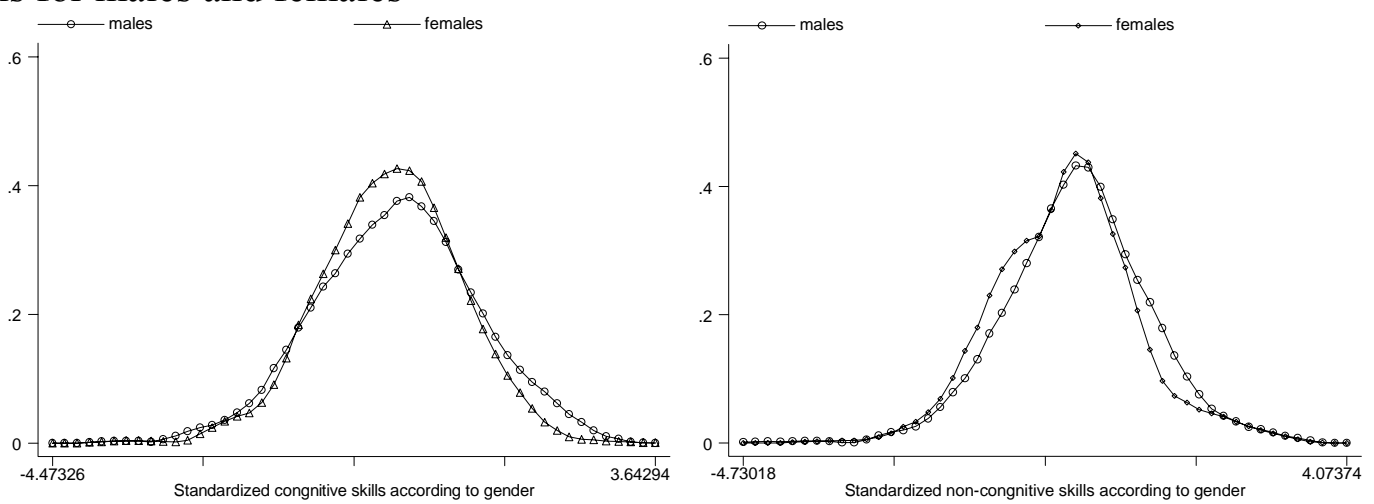

\section{Figure 5.2}

Sample distribution of standardized average measure of cognitive skills for males and females according to secondary school choice
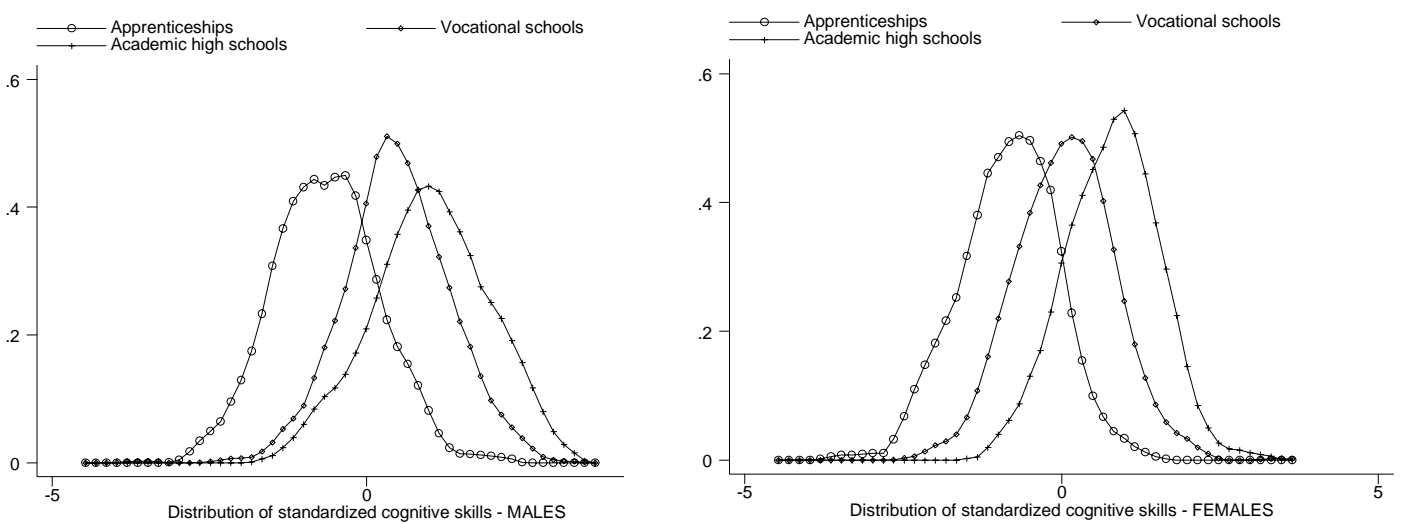

\section{Figure 5.3}

Sample distribution of standardized average measure of non-cognitive skills for males and females according to secondary school choice
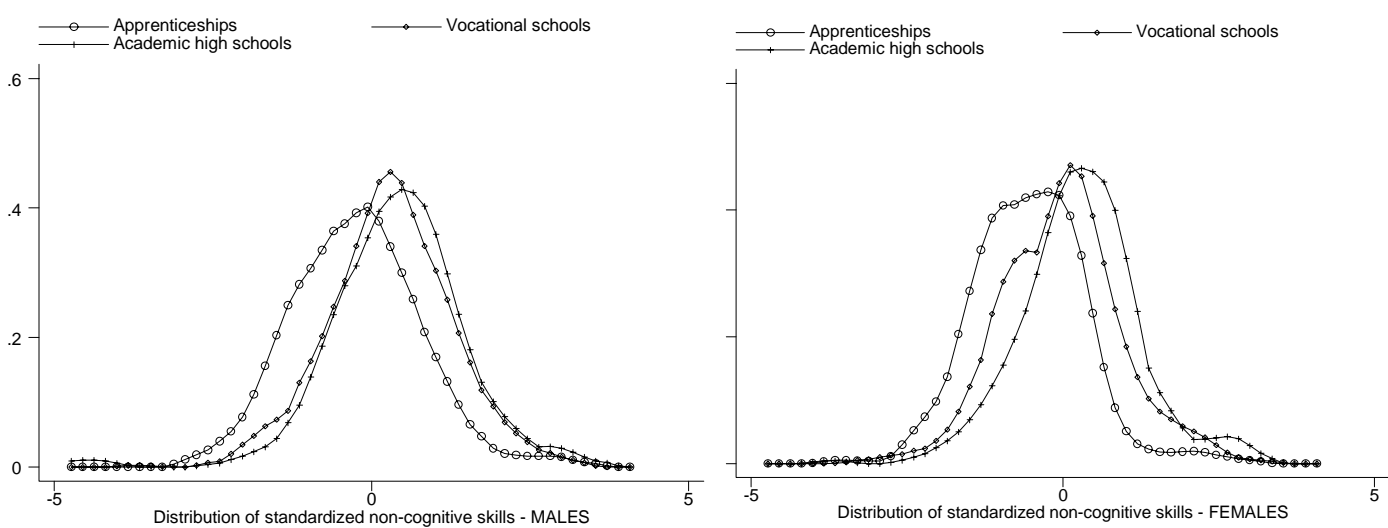


\section{Figure 5.4}

Choice of secondary school according to education of mother; males and females

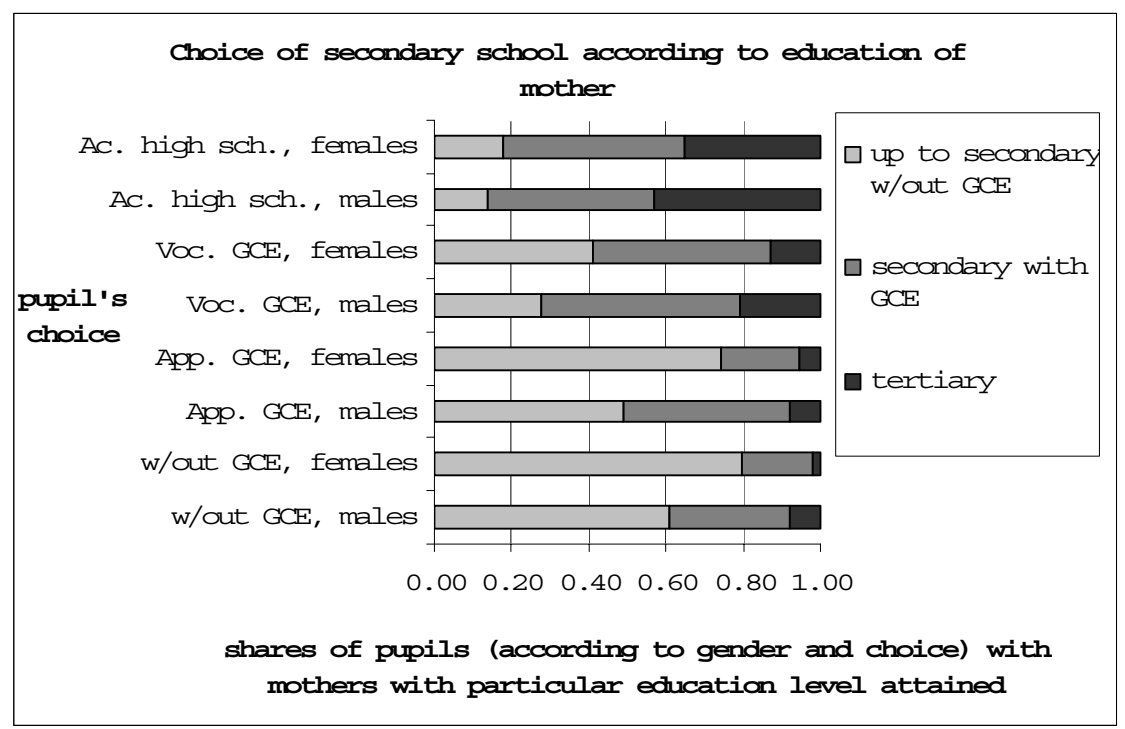

Figure 5.5

Choice of secondary school according to education of father; males and females

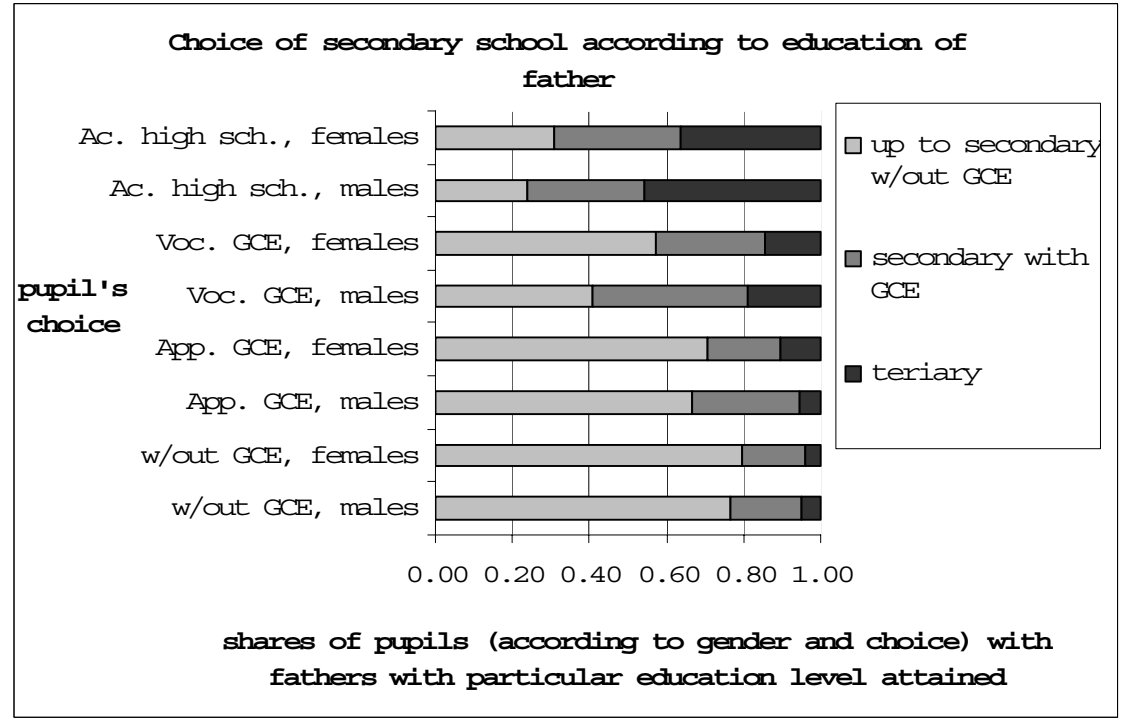




\section{Figure 5.6}

Percentage of academic high school programs out of all upper-secondary programs Percentage of 4-year academic high school programs out of all academic high school programs

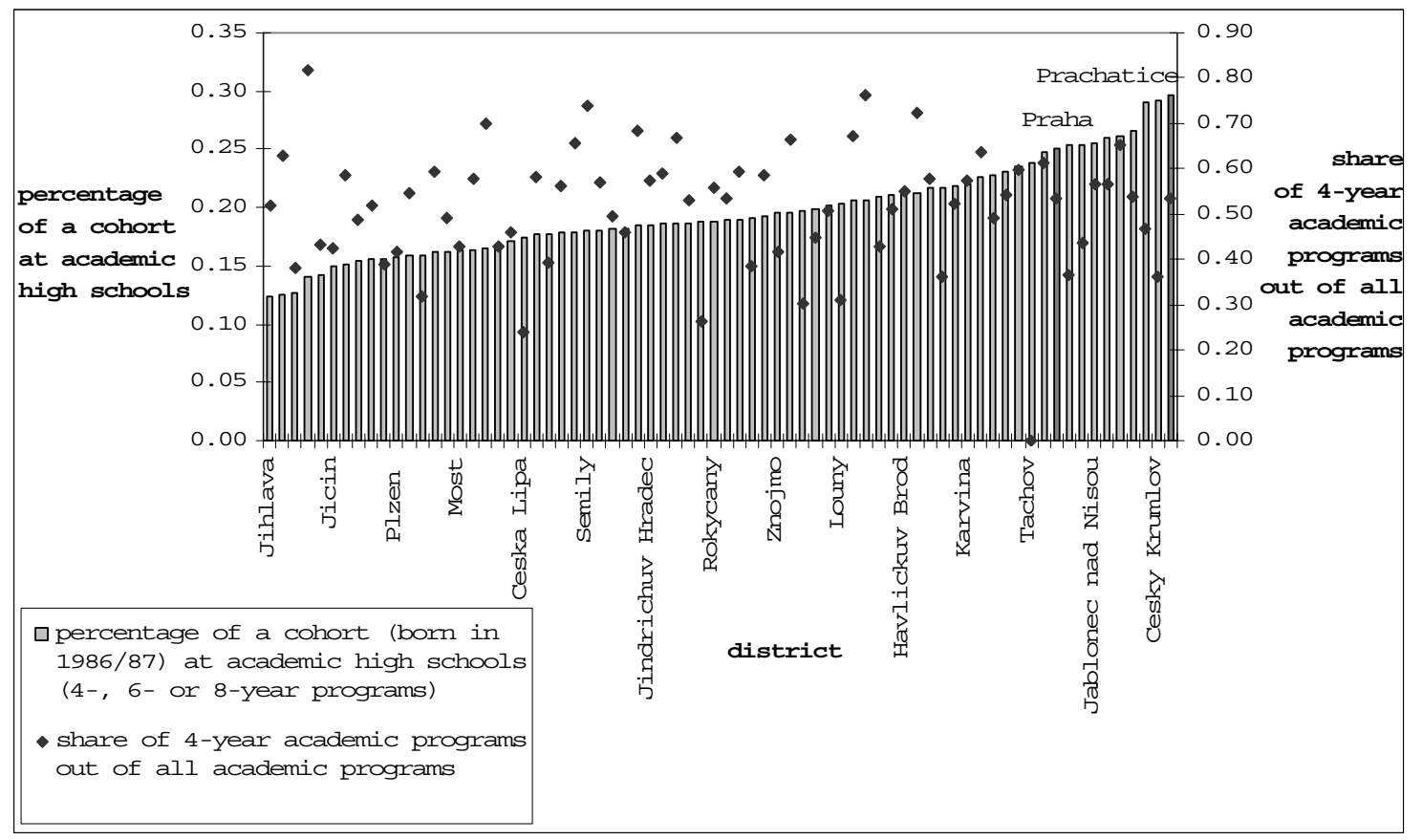

Figure 5.7

Share of the places available for elementary school graduates at particular school types

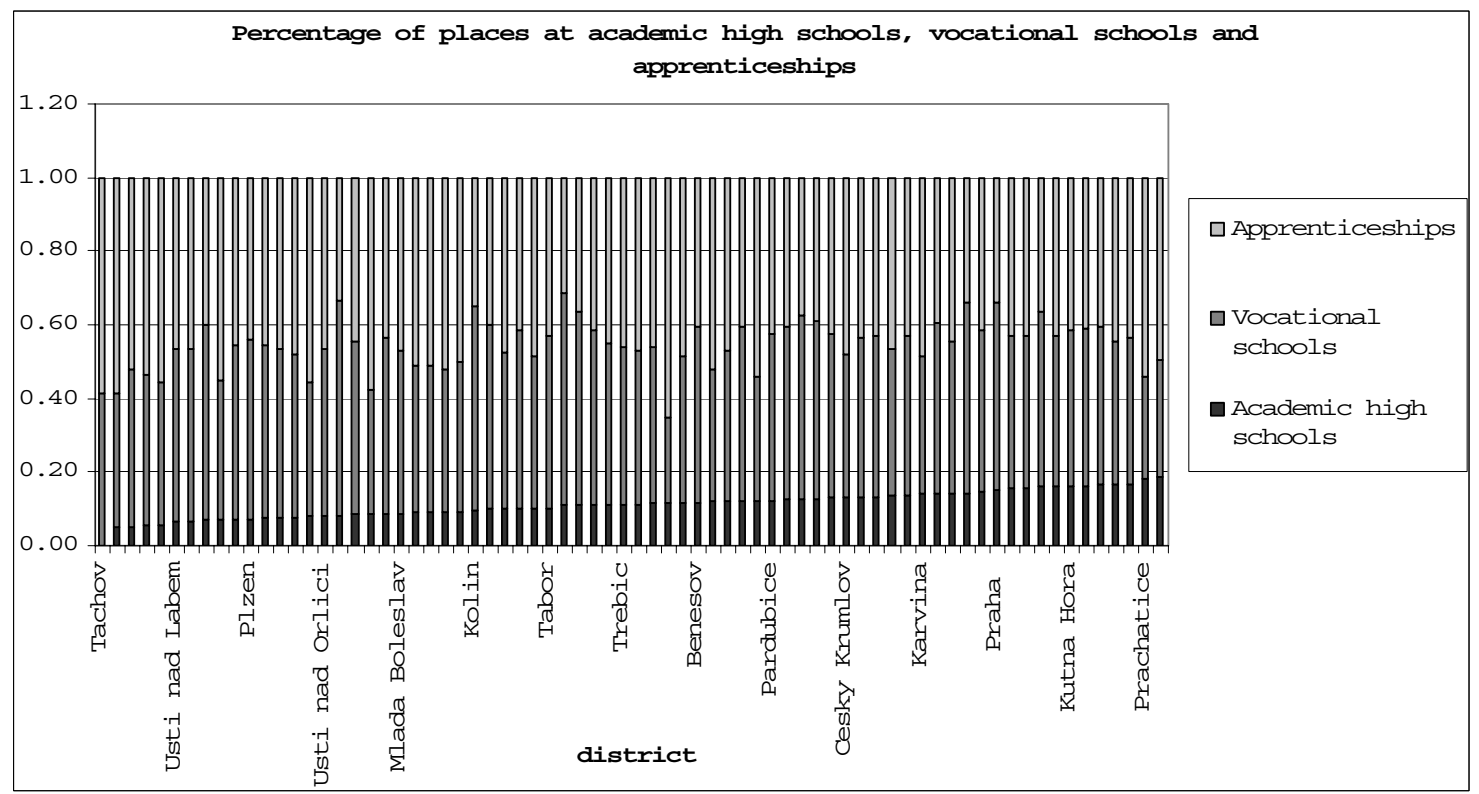


Figure 5.8

Predicted excess demand for academic high schools vs. the values of excess demand based on raw data

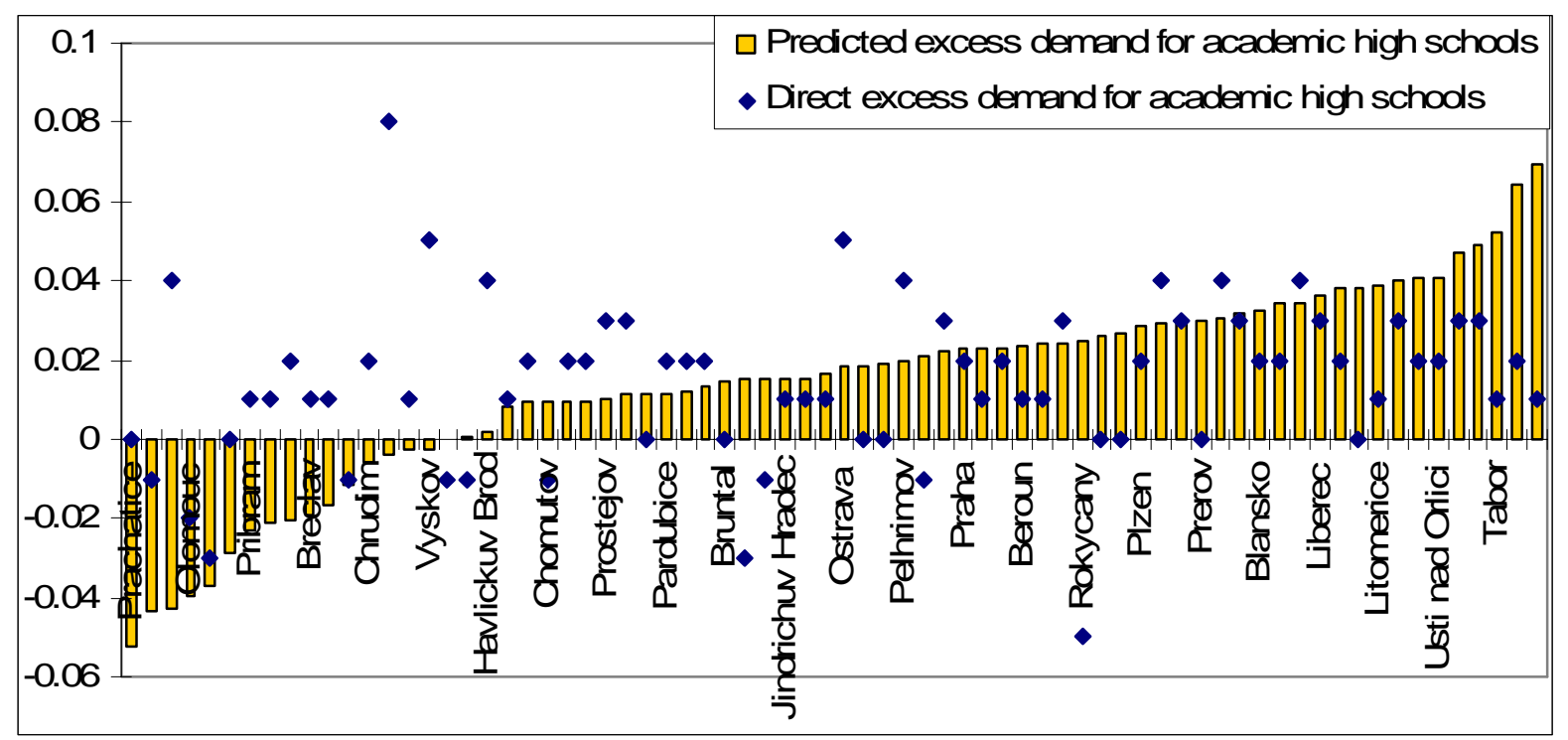

\section{Figure 5.9}

Predicted excess supply of apprenticeships vs. the values of excess supply based on raw data

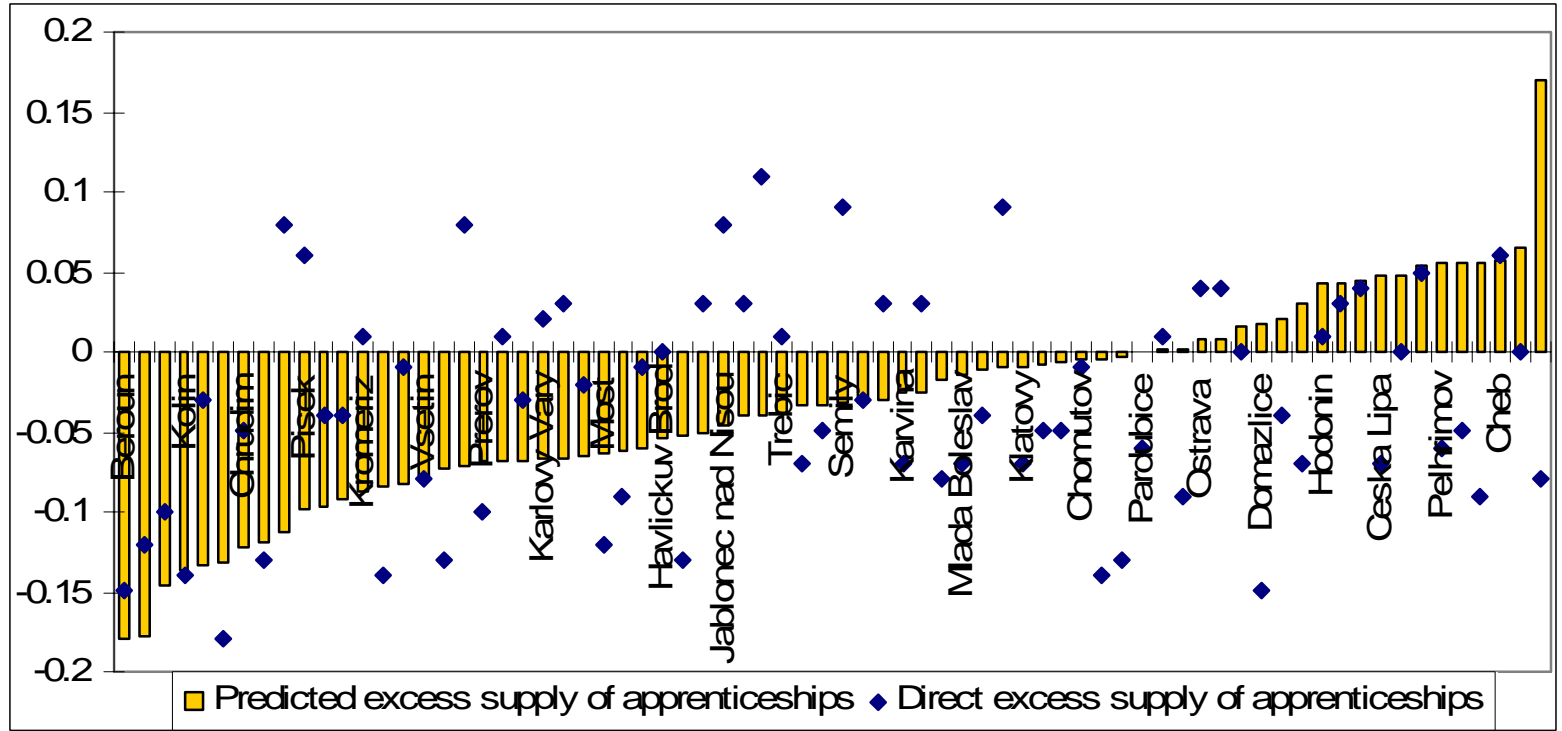




\section{Figure 6.2a)-d)}

Marginal effects and z-statistics of income per capita, education, cognitive and noncognitive skills on probability of males applying for academic high school for different values of excess demand

\section{2a)}

Marginal effect of income

\section{2b)}

Marginal effect of tertiary education of parents as opposed to secondary education of parents

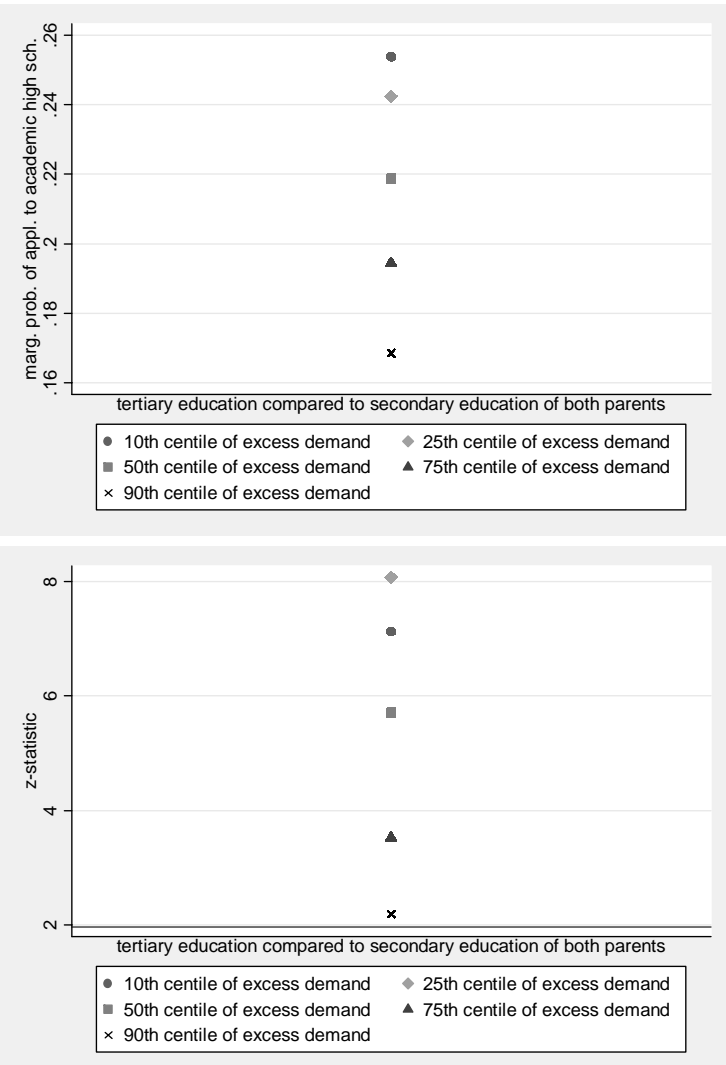


6.2c) Marginal effect of cognitive skills
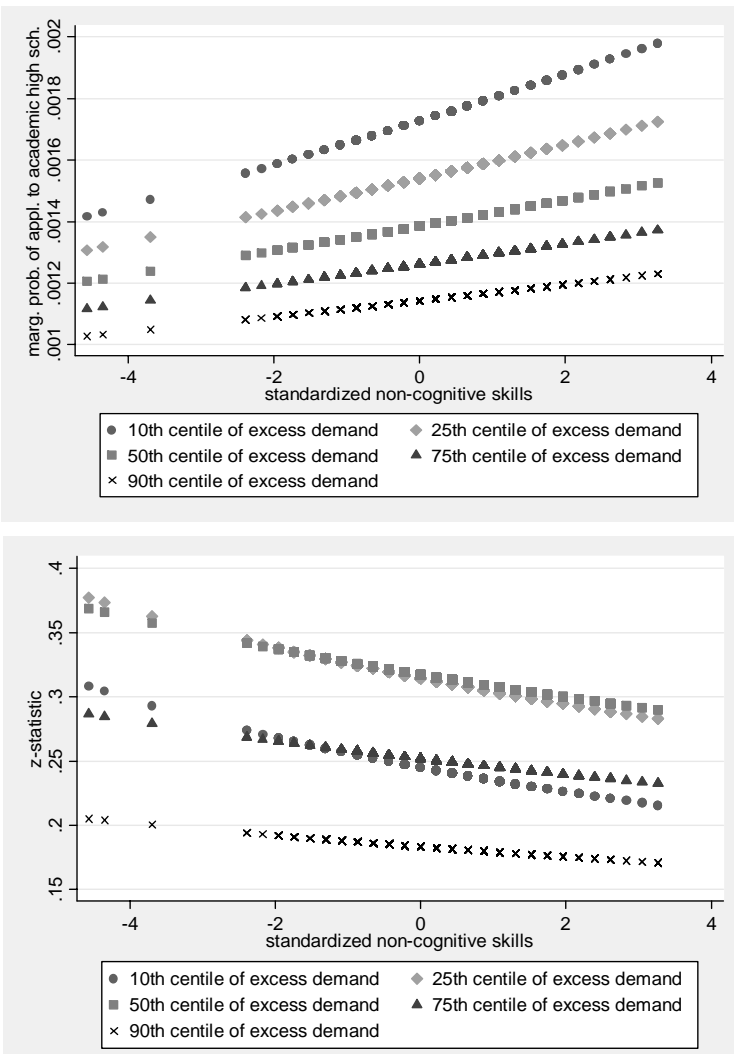

6.2d) Marginal effect of non-cognitive skills
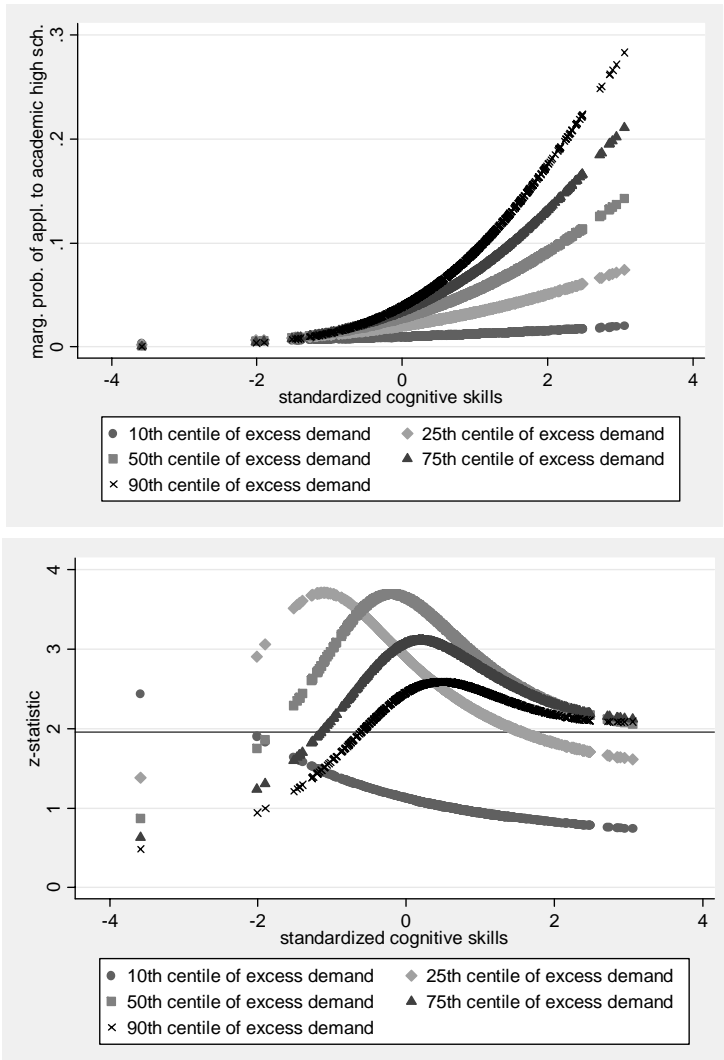


\section{Figure 6.3a)-d)}

Marginal effects and z-statistics of income per capita, education, cognitive and noncognitive skills on probability of females applying for academic high school for different values of excess demand

6.3a)

Marginal effect of income

\section{3b)}

Marginal effect of tertiary education of parents as opposed to secondary education of parents
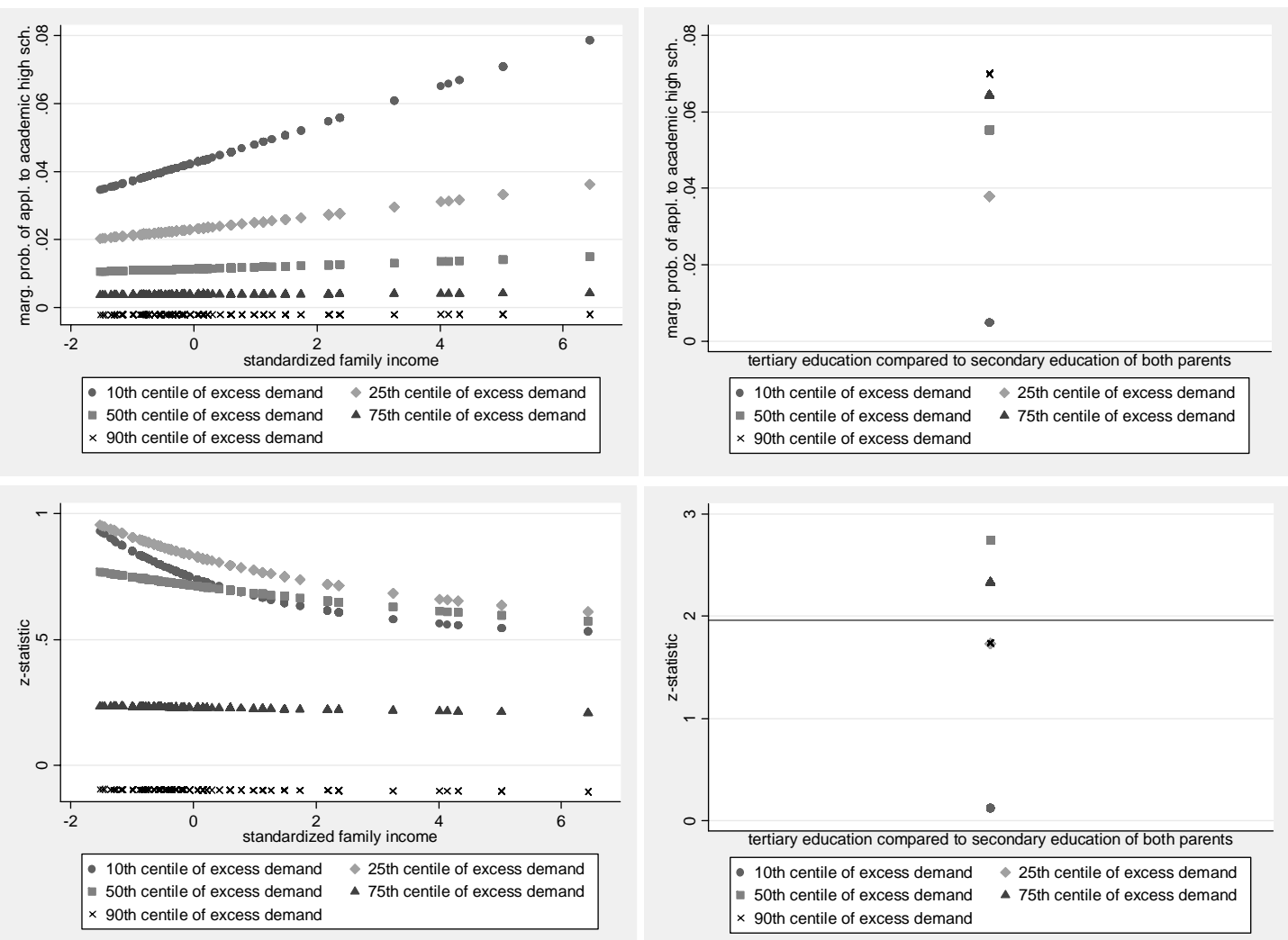
$6.3 \mathrm{c})$

Marginal effect of cognitive skills
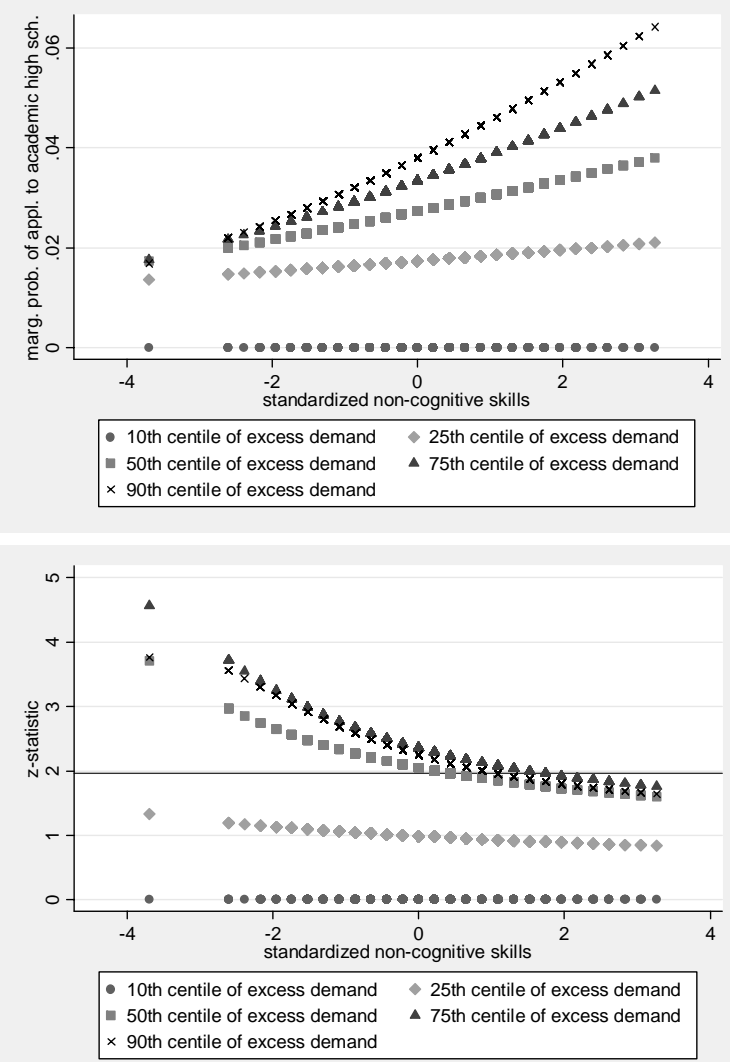

6.3d)

Marginal effect of non-cognitive skills
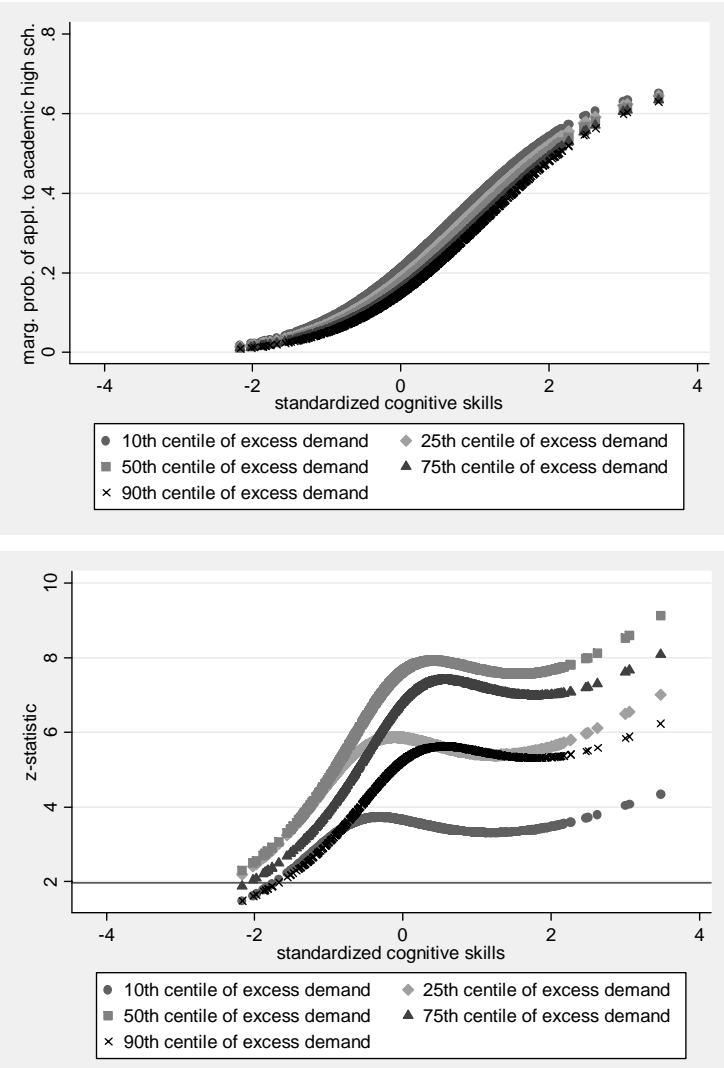


\section{Figure 6.4a)-d)}

Marginal effects and z-statistics of income per capita, education, cognitive and noncognitive skills and education on probability of males applying for apprenticeship for different values of excess supply of apprenticeships in a district

6.4a)

Marginal effect of income
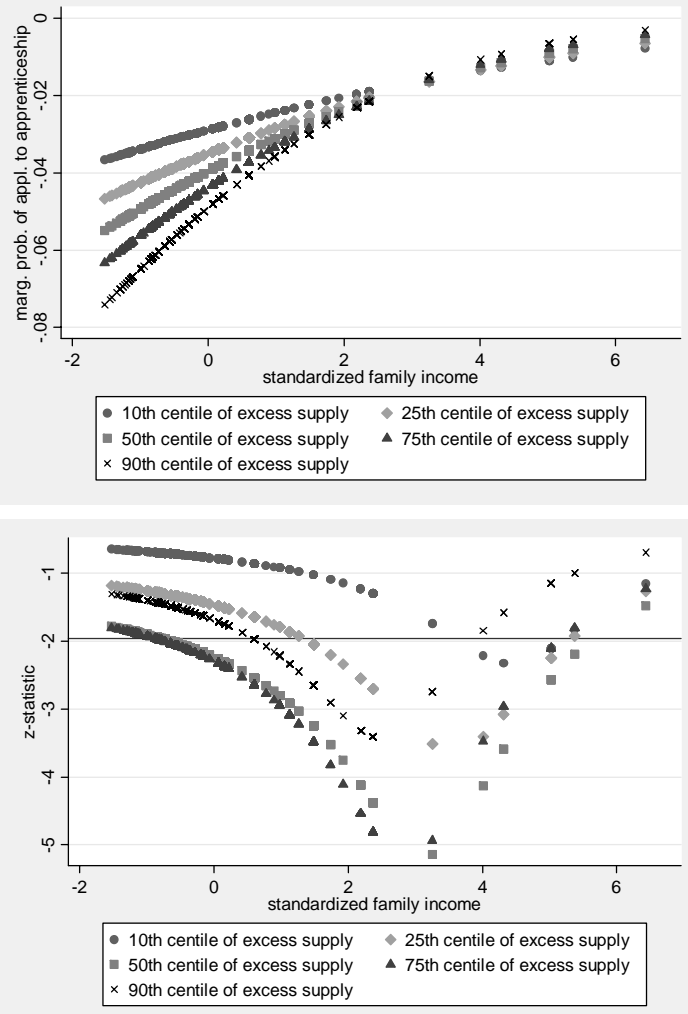

6.4b)

Marginal effect of tertiary education of parents as opposed to secondary education of parents
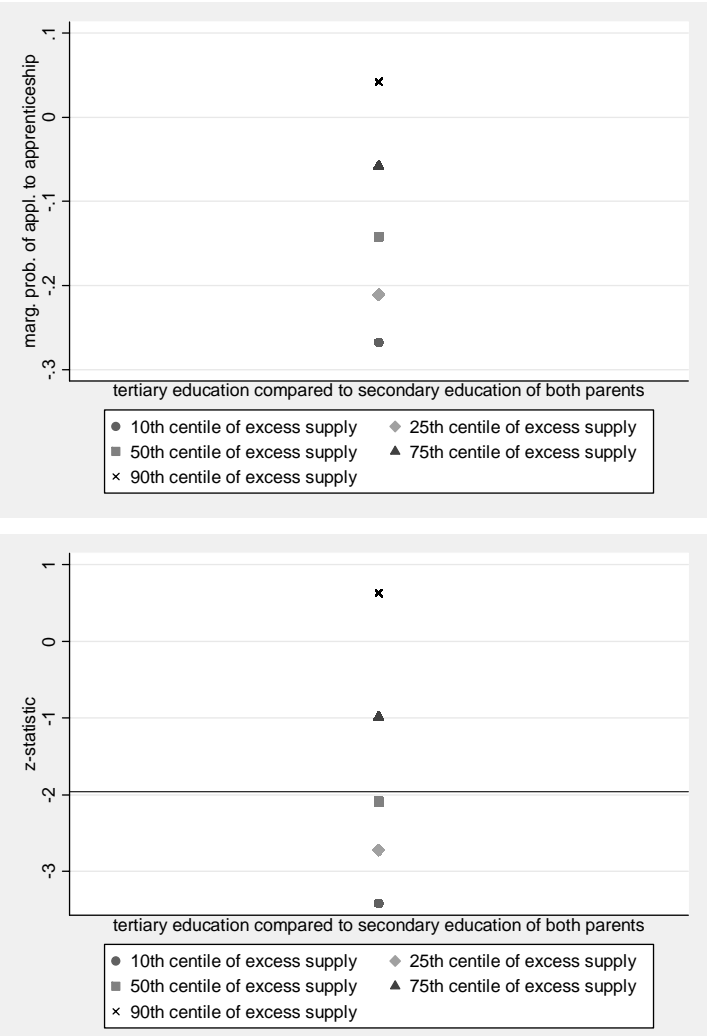
$6.4 c)$

Marginal effect of cognitive skills
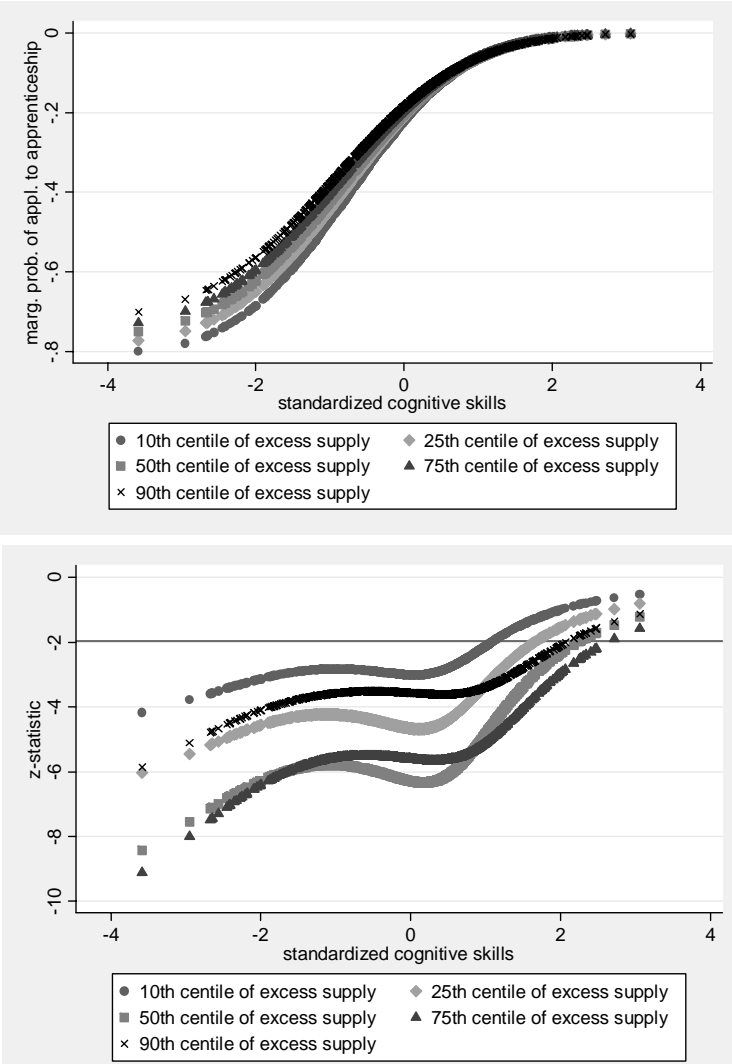

6.4d)

Marginal effect of non-cognitive skills
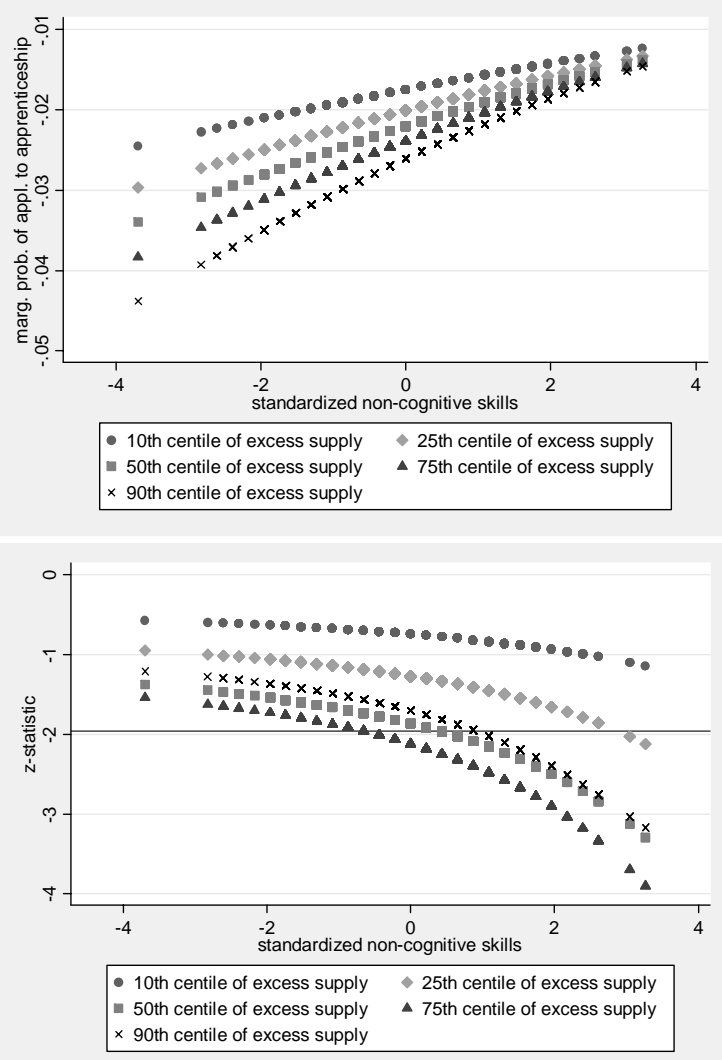


\section{Figure 6.5a)-d)}

Marginal effects and z-statistics of income per capita, education, cognitive and noncognitive skills on probability of females applying for apprenticeship for different values of excess supply of apprenticeships in a district

6.5a)

Marginal effect of income

\section{$6.5 b)$}

Marginal effect of tertiary education of parents as opposed to secondary education of parents

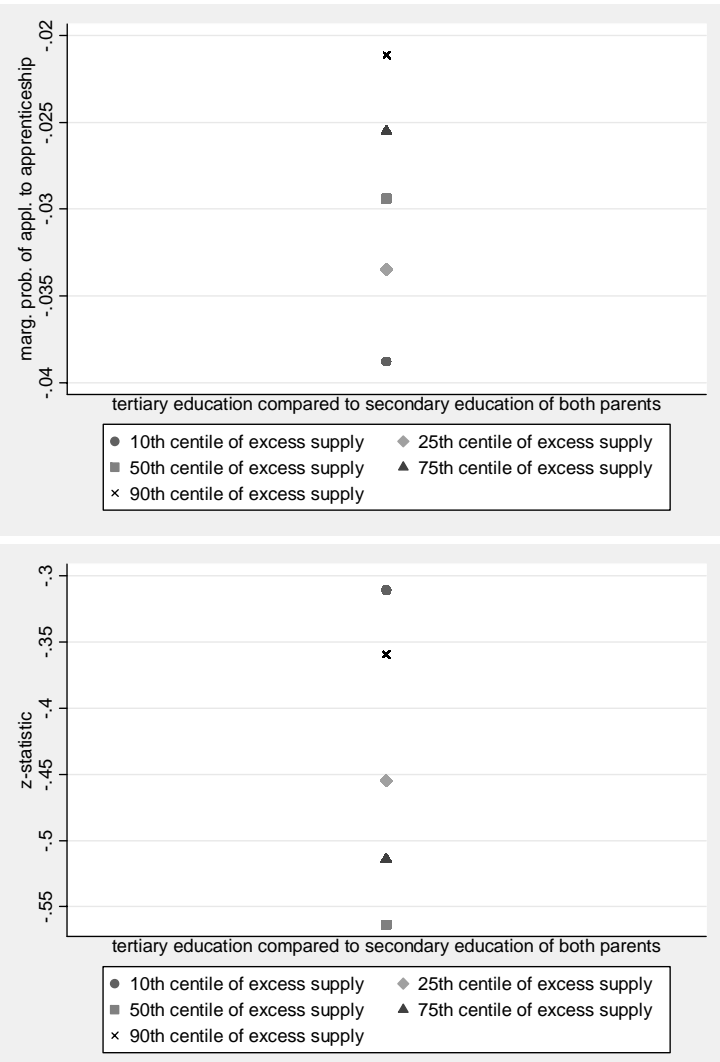


$6.5 \mathrm{c})$

Marginal effect of cognitive skills
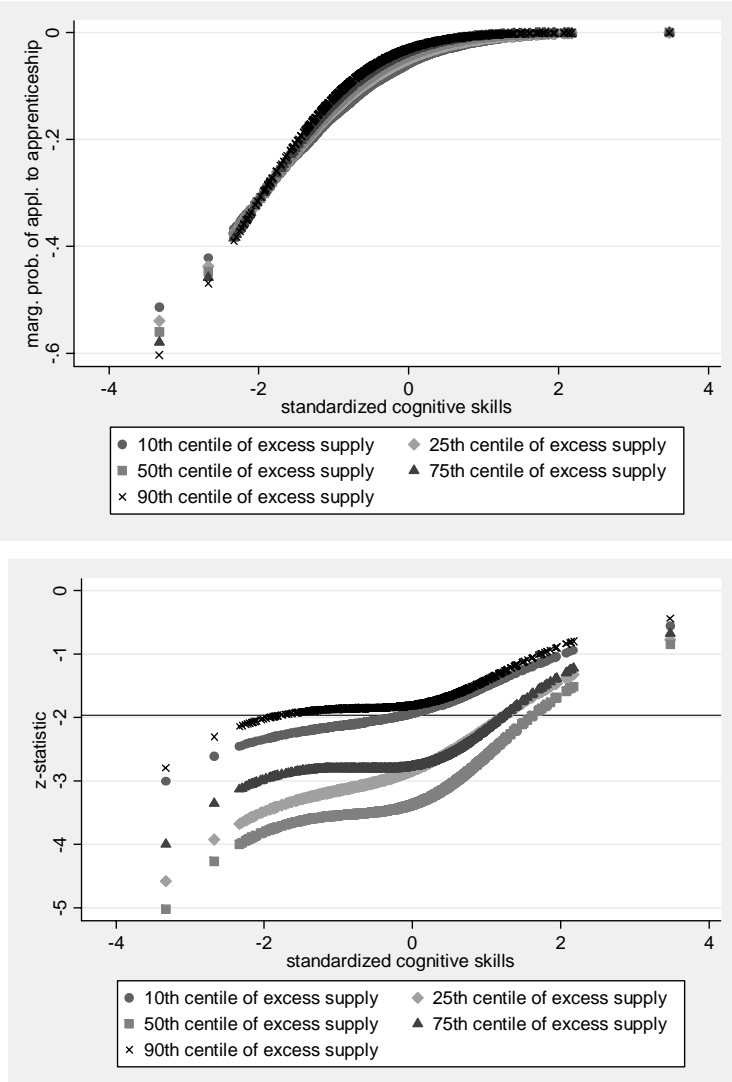

$6.5 \mathrm{~d})$

Marginal effect of non-cognitive skills
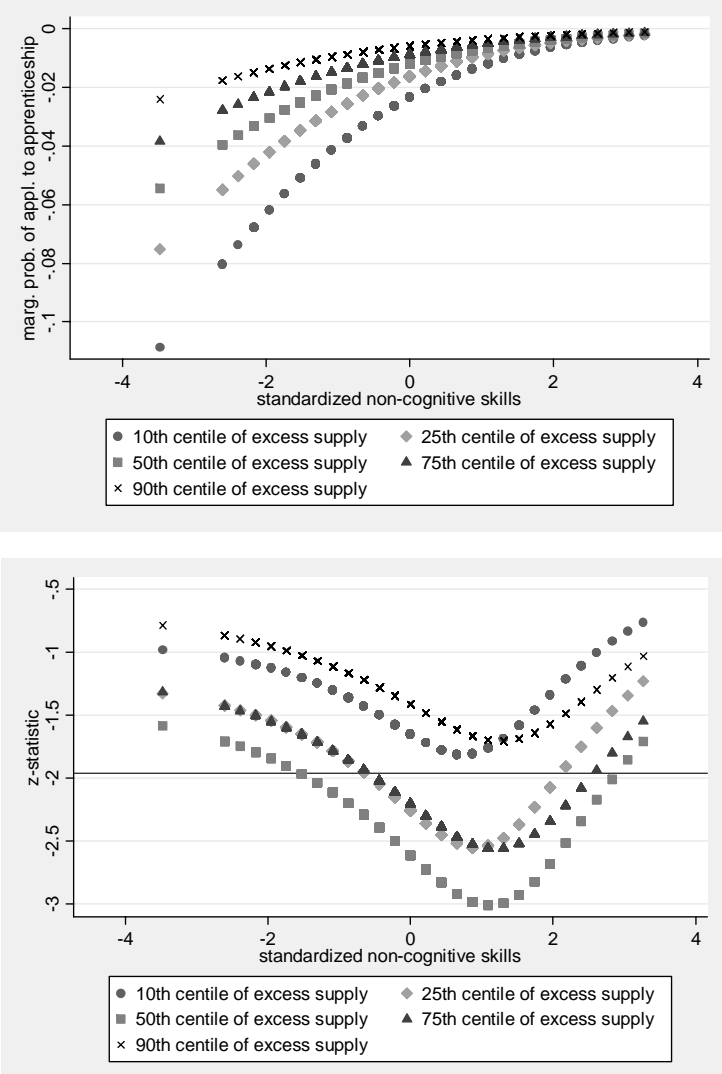


\section{Figure 6.6a), b)}

Predicted probability of applying to academic high school for males and females with different levels of cognitive and non-cognitive skills whose parents have both attained the secondary education

6.6a)

Fixed non-cognitive skills

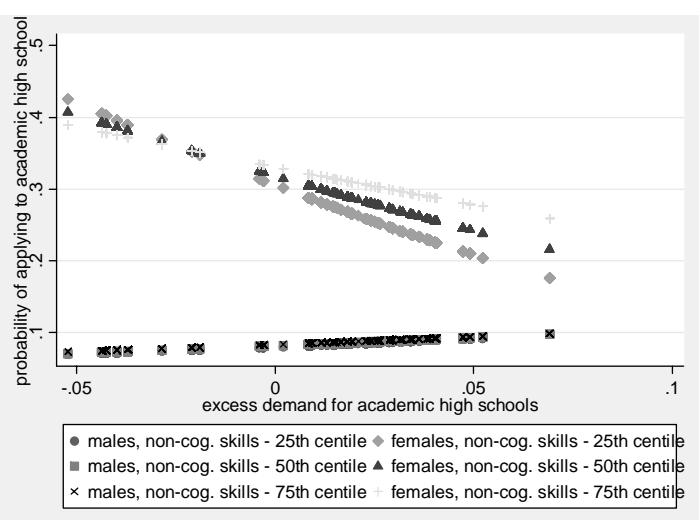

6.6b)

Fixed cognitive skills

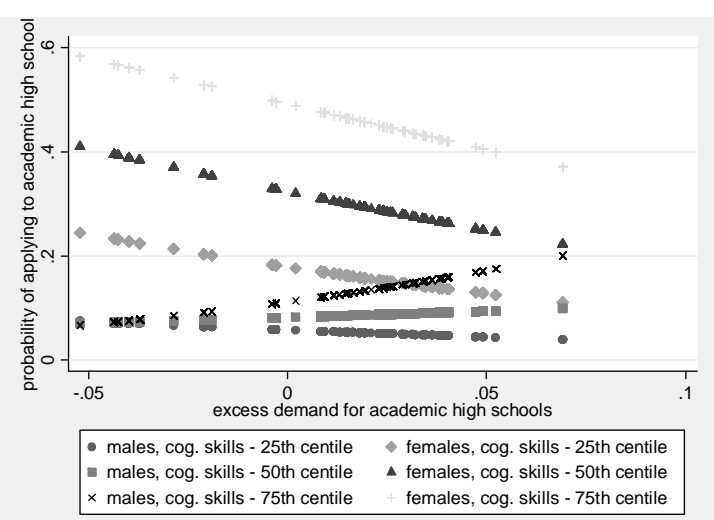

Figure 6.7a),b)

Predicted probability of applying to apprenticeship for males and females with different levels of cognitive and non-cognitive skills whose parents have both attained the secondary education

6.7a)

Fixed non-cognitive skills

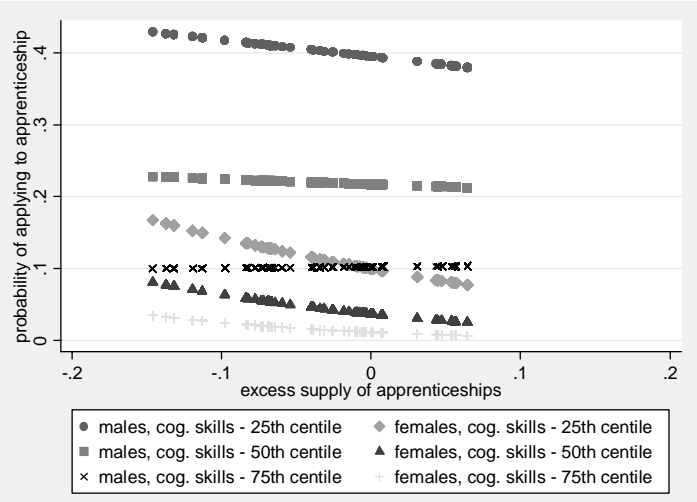

6.7b)

Fixed cognitive skills

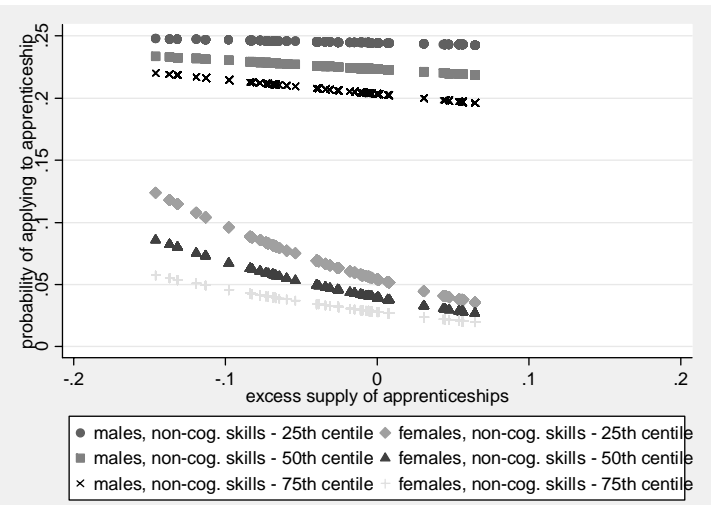




\section{APPENDIX 3 - DESCRIPTION OF PSYCHOLOGIC SCALES AND A MODEL OF CHOICE}

\section{Rosenberg Self-Esteem Scale}

Self-esteem is a positive or negative evaluation of one's worthiness. High selfesteem, indicates positive self-regard, not egoism. Question Q24 in a Complementary Pupil questionnaire contains 6 items of the scale designed by Rosenberg (1965).

Pupils were asked to assess the extent to which they agree with following statements. The possible answers were: I strongly agree, I agree, I disagree, I strongly disagree.

a) I feel that I'm a person of worth, at least on an equal plane with others.

b) I feel that I have a number of good qualities.

c) I certainly feel useless at times.

d) I am able to do things as well as most other people.

e) I feel I do not have much to be proud of.

f) All in all, I am inclined to feel that I am a failure.

\section{Rotter Locus of Control Scale}

The Rotter scale (1966) measures the extent individuals perceive they have over their lives as opposed to the extent they believe chance or fate predetermines their lives. Question Q25 in a Complementary Pupil Questionnaire contains seven items that are similar, or same as the original items in the Rotter scale.

Pupils were asked to assess the extent to which they agree with following statements. The possible answers were: I strongly agree, I agree, I disagree, I strongly disagree.

a) Some times I feel that in my life there is always someone who pushes me.

b) What happens to me is my own doing.

c) There are problems without solution.

d) I cannot do almost anything about changing some important things in my life.

e) Face to face my problems I often feel helpless.

f) Many times I feel that I have little influence over the things that happen to me.

g) I can achieve almost everything that I choose to.

\section{A Model of Choice}

I consider three types of secondary education present in the Czech Republic: apprenticeships that are mostly not concluded with general certified exams, vocational schools with GCE and academic high schools. ${ }^{15}$

\footnotetext{
${ }^{15}$ Indeed, there are various types inside each category, but PISA data do not provide information other than the choice at the general level. However, considering large differences between these types (GCE, potential for university education, blue-collar vs. white-collar professions), this division is sufficient.
} 
Individual's $\boldsymbol{i}$ decision process is theoretically constructed as follows. He associates a utility $\boldsymbol{U}_{i j}$ with the school type $\boldsymbol{j}$. He maximizes his expected utility he would get by getting to particular school types, multiplied by a factor that should reflect other influences unrelated or not captured by the expected utility:

$$
\begin{gathered}
\max _{j} \boldsymbol{V}_{i j}=\delta_{i j}\left[\boldsymbol{P}_{i j} \boldsymbol{U}_{i j}+\left(1-\boldsymbol{P}_{i j}\right) \overline{\boldsymbol{U}}_{i j}\right] \\
\boldsymbol{j}=1,2,3
\end{gathered}
$$

where $\overline{\boldsymbol{U}}_{i j}$ is the expected value of ending up at some other school type if getting to type $\boldsymbol{j}$ would be unsuccessful, ${ }^{16} \boldsymbol{P}_{\boldsymbol{i j}}$ is self-perceived probability of getting to type $\boldsymbol{j}$ and $\delta_{i j}$ is a specific factor capturing individual background characteristics that determines appropriateness, or feasibility of choice $\boldsymbol{j} . \boldsymbol{P}_{i j}$ is assumed to be a function of an individual's level of cognitive skills $\boldsymbol{f}_{i}{ }^{C}$, level of non-cognitive skills $\boldsymbol{f}_{i}{ }^{N}$ as well as a function of excess demand for school type $\boldsymbol{j}$ in a given district $\boldsymbol{D}, \boldsymbol{E} \boldsymbol{D}_{j}^{\boldsymbol{D}}:{ }^{17}$

$$
P_{i j}=P_{i j}\left(f_{i}^{C}, f_{i}^{N}, E D_{j}^{D}\right)
$$

Utility of individual $\boldsymbol{i}$ associated with choice $\boldsymbol{j}$ is also a function of the level of cognitive and non-cognitive skills, since a better match of skills with a school type produces better schooling outcome. It is also a function of school quality of type $\boldsymbol{j}$ in a district: $\boldsymbol{Q}_{j}^{\boldsymbol{D}}$ as well as some individual-specific, unobserved factor $\tau_{\boldsymbol{i}}$.

$$
U_{i j}=U_{i j}\left(f_{i}^{C}, f_{i}^{N}, Q_{j}^{D}, \tau_{i}\right)
$$

Application choice is also affected by background characteristics of a pupil. Variable $\delta_{i j}$ is a function of educational background of parents: $\boldsymbol{E D} \boldsymbol{U}_{\boldsymbol{i}}$, family income $\boldsymbol{I N C}_{\boldsymbol{i}}{ }^{18}$ and other unobserved characteristics accounting, e.g., for social status of a family or decision latitude allowed by parents to their child: $\widetilde{\tau}_{i}$.

\footnotetext{
${ }^{16}$ A student can actually end up at the same type of school he did not get into in the first round. This applies to, for example, ending up at a private academic high school after being rejected from a public academic high school.

${ }^{17}$ Excess demand is a variable capturing the difference between actual district supply of places at given school type and demand predicted based on characteristics of a district, such as educational structure, presence of university or labor market characteristics.

${ }^{18}$ Family income should capture how affordable it is for a pupil to go to private school. As noted by Filer and Munich (2002), the primary market for private schools are students not admitted to public academic high school. In 2002/2003, approximately 16,500 pupils applied to academic high schools in the first round. Total number of applications to private academic high schools amounted to 2400 , but it is likely that only few students applied solely to private academic high schools. Regarding vocational schools, around 50,000 pupils applied to public schools in the first round, 14000 in total to private vocational
} 


$$
\delta_{i j}=\delta_{i j}\left(E D U_{i}, I N C_{i}, \widetilde{\tau}_{i}\right)
$$

Given the different characteristics of academic high schools, vocational schools and apprenticeships, it is likely that utility associated with apprenticeships would be very low for an individual seeking GCE or even higher education. On the other hand, for pupils with (cognitive and/or non-cognitive) skills at the bottom part of the population distribution, utility associated with academic high schools would be very low since the requirements at academic high schools would not be matched with skills. For these pupils, also self-perceived probability of getting into an academic high school is likely to be very low. Therefore, within the outlined theoretical framework, it is probable that one group of pupils would actually make a decision between an academic high school and vocational school, with $\boldsymbol{V}_{\text {Apprenticeship }}<<\boldsymbol{V}_{\text {GrammarSchool }}$ and $\boldsymbol{V}_{\text {Apprenticeship }}<<\boldsymbol{V}_{\text {Vocationalschool }}$. The other group of pupils would decide between applying to a vocational school or an apprenticeship, with: $\boldsymbol{V}_{\text {GrammarSchool }}<<\boldsymbol{V}_{\text {Apprenticeship }}$ and $\boldsymbol{V}_{\text {GrammarSchool }}<<\boldsymbol{V}_{\text {Vocationalschool }}$.

schools. Again, unfortunately, there is no evidence about simultaneous applications to both private and public schools. 
Individual researchers, as well as the on-line and printed versions of the CERGE-EI Working Papers (including their dissemination) were supported from the following institutional grants:

- Center of Advanced Political Economy Research [Centrum pro pokročilá politickoekonomická studia], No. LC542, (2005-2009),

- Economic Aspects of EU and EMU Entry [Ekonomické aspekty vstupu do Evropské unie a Evropské měnové unie], No. AVOZ70850503, (2005-2010);

- Economic Impact of European Integration on the Czech Republic [Ekonomické dopady evropské integrace na ČR], No. MSM0021620846, (2005-2011);

Specific research support and/or other grants the researchers/publications benefited from are acknowledged at the beginning of the Paper.

(c) Lenka Drnáková, 2007

All rights reserved. No part of this publication may be reproduced, stored in a retrieval system or transmitted in any form or by any means, electronic, mechanical or photocopying, recording, or otherwise without the prior permission of the publisher.

Published by

Charles University in Prague, Center for Economic Research and Graduate Education (CERGE) and

Economics Institute ASCR, v. v. i. (EI)

CERGE-El, Politických vězňů 7, 11121 Prague 1, tel.: +420 224005 153, Czech Republic.

Printed by CERGE-EI, Prague

Subscription: CERGE-EI homepage: http://www.cerge-ei.cz

Editors: Directors of CERGE and EI

Managing editors: Deputy Directors for Research of CERGE and EI

ISSN 1211-3298

ISBN 978-80-7343-140-2 (Univerzita Karlova. Centrum pro ekonomický výzkum

a doktorské studium)

ISBN 978-80-7344-129-6 (Národohospodářský ústav AV ČR, v. v. i.) 
CERGE-EI

P.O.BOX 882

Politických vězňů 7

11121 Praha 1

Czech Republic http://www.cerge-ei.cz 